\title{
Ingenol Disoxate: A Novel 4-Isoxazolecarboxylate Ester of Ingenol with Improved Properties for Treatment of Actinic Keratosis and Other Non-Melanoma Skin Cancers
}

\author{
Malene Bertelsen (D) - Martin Stahlhut - Gunnar Grue-Sørensen • Xifu Liang • \\ Gitte Bach Christensen · Kresten Skak · Karen Margrethe Engell · Thomas Högberg
}

Received: July 6, 2016/ Published online: August 8, 2016

(C) The Author(s) 2016. This article is published with open access at Springerlink.com

\begin{abstract}
Introduction: Ingenol mebutate gel $\left(\right.$ Picato $^{\circledR}$, LEO Pharma A/S) is approved for the field treatment of actinic keratosis and is characterized by high sustained clearance of actinic lesions. The inherent propensity of ingenol mebutate towards chemical rearrangement necessitates refrigeration of the final product. We sought to identify novel ingenol derivatives with enhanced chemical stability and similar or improved in vitro potency and in vivo efficacy.
\end{abstract}

Enhanced content To view enhanced content for this article go to http://www.medengine.com/Redeem/ 49E4F06039AB62DD.

Electronic supplementary material The online version of this article (doi:10.1007/s13555-016-0137-2) contains supplementary material, which is available to authorized users.

M. Bertelsen ( $\square)$ · M. Stahlhut · G. B. Christensen · K. Skak

Skin Research, LEO Pharma A/S, Ballerup, Denmark e-mail: MVBDK@leo-pharma.com

G. Grue-Sørensen · X. Liang · T. Högberg ( $₫)$ Drug Design, LEO Pharma A/S, Ballerup, Denmark e-mail: THGDK@leo-pharma.com

K. M. Engell

Pharmaceutical Design and Development, LEO

Pharma A/S, Ballerup, Denmark
Methods: A number of ingenol esters were synthesized with full regiocontrol from ingenol. Chemical stability was determined in aqueous buffer at physiological $\mathrm{pH}$ and hydroalcoholic gel at lower $\mathrm{pH}$. Acute cytotoxicity was determined in HeLa or HSC-5 cells. Keratinocyte proliferation, viability and caspase 3/7 activation was measured in primary epidermal keratinocytes. Relative gene expression levels were determined by real-time quantitative PCR. Evaluation of in vivo tumor ablating potential was performed in the murine B16 melanoma mouse model and in the UV-induced skin carcinogenesis model in hairless SKH-1 mice following topical treatment for two consecutive days with test compounds formulated at $0.1 \%$ in a hydroalcoholic gel.

Results: This work resulted in the identification of ingenol disoxate (LEO 43204) displaying increased stability in a clinically relevant formulation and in aqueous buffer with minimal pH-dependent acyl migration degradation. Ingenol disoxate exhibited a significantly higher cytotoxic potency relative to ingenol mebutate. Likewise, cell growth arrest in normal human keratinocyte was more 
potently induced by ingenol disoxate, which was accompanied by protein kinase $\mathrm{C}$ dependent transcription of markers of keratinocyte differentiation. Most notably, ingenol disoxate possessed a superior antitumor effect in a B16 mouse melanoma model and significantly increased median survival time relative to ingenol mebutate. A significant effect on tumor ablation was also observed in a murine model of ultraviolet irradiation-induced skin carcinogenesis.

Conclusion: These data illustrate that the favorable in vitro and in vivo pharmacological properties driving ingenol mebutate efficacy are either preserved or improved in ingenol disoxate. In combination with improved chemical stability to potentially facilitate storage of the final product at ambient temperatures, these features support further development of ingenol disoxate as a convenient and efficacious treatment modality of non-melanoma skin cancers.

Funding: LEO Pharma A/S.

Keywords: Animal tumor models; Antiproliferative; Chemical stability; Cytotoxicity; Ingenol derivatives; Pro-inflammatory; Regiocontrolled syntheses; Skin cancer

\section{INTRODUCTION}

Actinic (solar) keratosis (AK) is a skin disease found in high prevalence in populations with fair skin as a result of significant, chronic exposure to ultraviolet radiation (UVR) [1-3]. AK lesions are regarded as premalignant lesions that unpredictably can progress into squamous cell carcinoma (SCC), if left untreated. Although liquid nitrogen cryotherapy and surgical interventions are efficacious treatment options against individual AK lesions, well-tolerated and effective therapies treating the entire UV-induced field change with good cosmetic outcome are essential to ensure high sustained clearance and a good long-term outcome for the patient [4, 5]. Traditionally, 5-fluorouracil, imiquimod, and diclofenac are used in field therapy with treatment lengths over weeks or months with photodynamic therapy (PDT) offering an alternative approach $[4,6]$.

Recently, ingenol mebutate gel (Picato ${ }^{\circledR}$, LEO Pharma A/S) was introduced to the market for topical field treatment of $\mathrm{AK}$ in a contiguous skin area of approximately $25 \mathrm{~cm}^{2}[7,8]$. Ingenol mebutate (1) is a naturally occurring 3-monoester of ingenol (2) and angelic acid (Fig. 1), which has been used in traditional medicine to treat various skin conditions.

Ingenol mebutate can be isolated from the Euphorbia peplus (petty spurge) plant $[9,10]$, but it can also be prepared by an efficient semisynthesis from the diterpene ingenol [11]. Topical treatment with ingenol mebutate gel for two or three consecutive days has been associated with high clearance rates, modest local skin responses and sustained clearance of AK lesions in patients at 1-year follow-up [12]. The clinical efficacy of ingenol mebutate against $\mathrm{AK}$ is believed to be linked to a dual mechanism of action, i.e., (1) induction of local cell death and (2) induction of a local immune response, which at least partially, is mediated by the activation of protein kinase $\mathrm{C}$ (PKC) [13-16].

The marketed ingenol mebutate gel needs to be refrigerated due to the limited chemical stability of ingenol mebutate and we have therefore been seeking more stable products with similar or improved in vitro potency and in vivo efficacy. We have previously published some of our efforts towards novel analogues of 


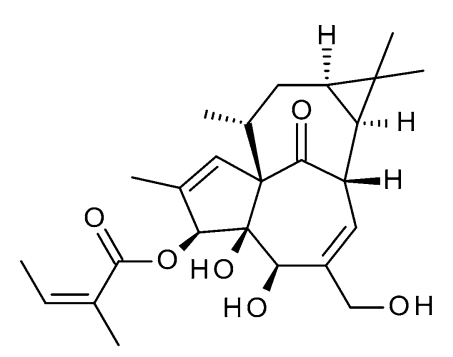

Ingenol mebutate (1)

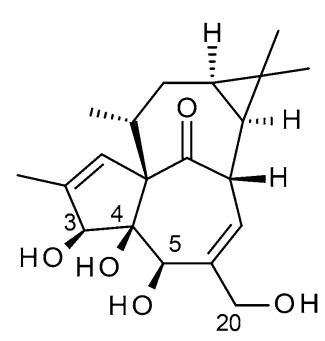

Ingenol (2)

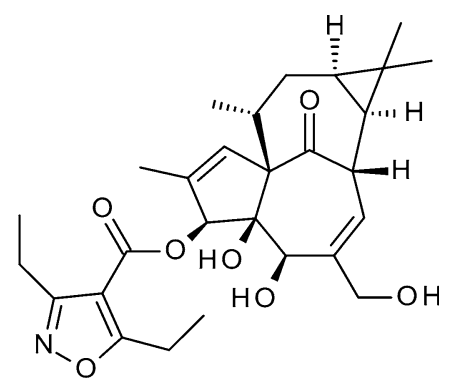

Ingenol disoxate (3)

Fig. 1 Comparison of the chemical structures of ingenol mebutate (1), ingenol (2) and ingenol disoxate (3, LEO 43204)

ingenol mebutate having improved physicochemical properties $[17,18]$, such as chemical stability and preserved favorable in vitro pharmacological properties. Some key findings from the structure-activity studies should be pointed out: (1) methylation of the 5- or 20-hydroxyl groups in the rigid ingenol scaffold eliminated the biological effects, (2) ingenol itself lacks biological activity, (3) the carbonyl moiety of the ester groups is essential for biological effects and the activation of PKC, likely via an interaction with the Gly23 $\mathrm{NH}$ in the C1 domain, and (4) the 4-, 5-, and 20-hydroxyl groups form a framework for a pH-dependent acyl migration of the ester moiety leading to degradation of ingenol mebutate resulting in limited shelf life [17]. A recent study on a series of ingenol scaffold-modified cyclohexyl esters showed that complete removal of the 4- or 5-hydroxyl groups led to a moderate drop in activity, whereas removal of both hydroxyl groups resulted in a significant loss in activity [19]. The chemical stability could be improved by having substituents flanking the ester group, but this often resulted in reduced potency $[17,18]$. A series of substituted benzoate esters provided a reasonable compromise of features for enhanced stability and good potency as exemplified with the anthranilate $\mathbf{1 0}$ and salicylate 11-both capable of forming intramolecular hydrogen bonds (Table 1) [18]. However, the overall properties were not deemed sufficiently good to continue development.

In this work, we present a further improved ingenol ester with the international nonproprietary name ingenol disoxate, utilizing a heterocyclic 3-carboxylate, i.e., the ingenol 3O-[3,5-diethyl-4-isoxazolecarboxylate] (LEO 43204, 3) shown in Fig. 1. Our preclinical profiling efforts demonstrated that the cytotoxic and pro-inflammatory potency is similar or improved compared to ingenol mebutate. Most notably, ingenol disoxate possessed a superior antitumor effect in a B16 mouse melanoma model and significantly increased median survival time relative to ingenol mebutate. A significant effect on tumor ablation was also observed in a murine UV-induced tumor model.

\section{METHODS}

\section{Chemistry}

\section{General}

${ }^{1} \mathrm{H}$ nuclear magnetic resonance (NMR) spectra were recorded at 300 or $600 \mathrm{MHz}$ unless otherwise specified. Chemical shift values 
Table 1 Overview and numbering of ingenol derivatives

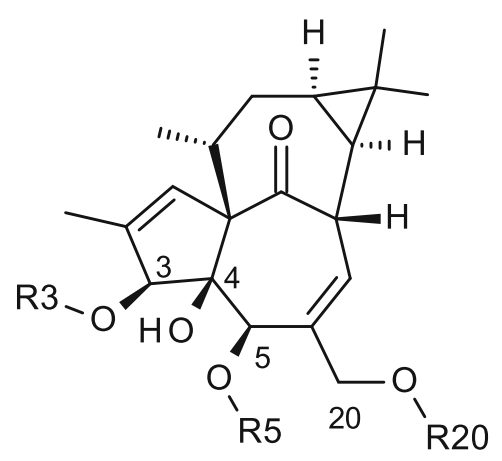

I<smiles>C/C=C(/C)C(C)=O</smiles>

III

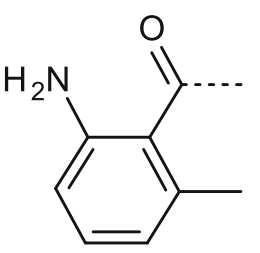

II

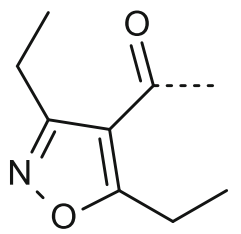

IV

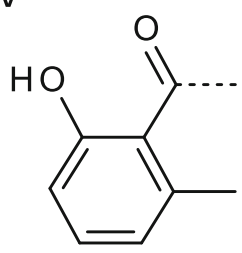

\begin{tabular}{lllll}
\hline No. & Name & R3 & R5 & R20 \\
\hline 1 & Ingenol mebutate & I & H & H \\
2 & Ingenol & H & H & H \\
3 & Ingenol disoxate & II & H & H \\
5 & & H & 5,20 -acetonide & \\
6 & PEP 015 & H & I & H \\
7 & PEP 025 & H & H & I \\
8 & & H & II & H \\
9 & & H & H & II \\
10 & & III & H & H \\
11 & & IV & H & H \\
12 & & H & H & TBDMS \\
13 & & TMS & H & TBDMS \\
\hline
\end{tabular}

TBDMS t-butyldimethylsilyl, TMS trimethylsilyl

$(\delta$, in $\mathrm{ppm})$ are quoted relative to internal tetramethylsilane $(\delta=0.00)$ standards. The value of a multiplet, either defined doublet $(\mathrm{d})$, triplet $(\mathrm{t})$, quartet $(\mathrm{q})$ or not $(\mathrm{m})$ at the approximate midpoint is given unless a range is quoted. (br) indicates a broad peak, whilst (s) indicates a singlet. The organic solvents used were usually anhydrous. Chromatography was performed on Merck silica gel 60 $(0.040-0.063 \mathrm{~mm})$. The solvent ratios indicated refer to v:v unless otherwise noted. All NMR spectra are recorded in DMSO- $d_{6}$ unless another solvent is stated. The purity and identity were determined on a Waters LCT Premier MS instrument and a Waters Acquity UPLC with a HSS T3 $1.8 \mu \mathrm{m}, 2.1 \times 50 \mathrm{~mm}$, column at $40^{\circ} \mathrm{C}$ with a gradient of solvents A $(10 \mathrm{mM}$ ammonium acetate $+0.1 \% \mathrm{HCOOH}$ ) and $\mathrm{B}$ $(\mathrm{MeCN}+0.1 \% \mathrm{HCOOH})$ starting $99 \% \mathrm{~A}$ and ending with $5 \% \mathrm{~A}$. 


\section{Chemical Synthesis Procedures}

Ingenol 3-Angelate (Ingenol Mebutate, 1) Synthesized from ingenol via ingenol-5,20-acetonide (5) according to our previously described procedure [11].

Ingenol 5-Angelate (PEP 015, 6) and Ingenol 20-Angelate (PEP 025, 7) Obtained from Peplin Operations Pty Ltd (Southport, QLD, Australia), which is a wholly owned subsidiary of LEO Pharma A/S.

\section{3,5-Diethylisoxazole-4-Carbonyl}

Chloride

(4) Oxalyl chloride $(1.79 \mathrm{~g}, 1.23 \mathrm{~mL}$, $14.1 \mathrm{mmol}$ ) was added drop wise to a solution of 3,5-diethylisoxazole-4-carboxylic acid $(1.91 \mathrm{~g}, 11.3 \mathrm{mmol})$ and dimethylformamide (DMF) $(0.3 \mathrm{~mL})$ in dichloromethane $(14 \mathrm{~mL})$ at room temperature for $7 \mathrm{~min}$. The solution was stirred at this temperature for $1 \mathrm{~h}$ and concentrated in vacuo, giving the title compound, which was used directly in the next step without characterization.

Ingenol-5,20-Acetonide-3-(3,5-Diethylisoxazole4-Carboxylate) A reaction solution of 3,5diethylisoxazole-4-carbonyl chloride $(4,11.3$ mmol), $N, \quad N$-diisopropylethylamine $\quad(2.91 \mathrm{~g}$, $3.85 \mathrm{~mL}, 22.5 \mathrm{mmol})$, 4-dimethylaminopyridine (275 mg, $2.25 \mathrm{mmol}$ ), and ingenol-5,20-acetonide $(5,1.75 \mathrm{~g}, 4.5 \mathrm{mmol})$ in acetonitrile $(12 \mathrm{~mL})$ in sealed vial was microwaved at $150{ }^{\circ} \mathrm{C}$ for $30 \mathrm{~min}$. The reaction mixture was poured into brine and extracted twice with ethyl acetate. The combined organic phases were dried over $\mathrm{Na}_{2} \mathrm{SO}_{4}$ and concentrated in vacuo. The residue was purified by flash chromatography (heptane/ethyl acetate $3: 1)$, giving the title product $(2.27 \mathrm{~g}, 94 \%)$ as a white solid.

${ }^{1} \mathrm{H}$ NMR $\left(300 \mathrm{MHz}, \mathrm{CDCl}_{3}\right) \delta$ 6.13-6.11 (m, $1 \mathrm{H}), 5.82-5.80(\mathrm{~m}, 1 \mathrm{H}), 5.73(\mathrm{~s}, 1 \mathrm{H}), 4.28-4.11$ $(\mathrm{m}, 3 \mathrm{H}), 4.05(\mathrm{~m}, 1 \mathrm{H}), 3.26(\mathrm{~s}, 1 \mathrm{H}), 3.09(\mathrm{q}$, $J=7.5 \mathrm{~Hz}, \quad 2 \mathrm{H}), \quad 2.89 \quad(\mathrm{q}, \quad J=7.5 \mathrm{~Hz}, 2 \mathrm{H})$, 2.62-2.57 (m, 1H), 2.34-2.24 (m, 1H), $1.81(\mathrm{~d}$, $J=1.5 \mathrm{~Hz}, 3 \mathrm{H}), 1.79-1.70(\mathrm{~m}, 1 \mathrm{H}), 1.48(\mathrm{~s}, 3 \mathrm{H})$, $1.45(\mathrm{~s}, 3 \mathrm{H}), 1.30(\mathrm{t}, J=7.5 \mathrm{~Hz}, 3 \mathrm{H}), 1.27(\mathrm{t}$, $J=7.5 \mathrm{~Hz}, 3 \mathrm{H}), 1.08(\mathrm{~s}, 3 \mathrm{H}), 1.05(\mathrm{~s}, 3 \mathrm{H}), 1.01$ $(\mathrm{d}, J=7.2 \mathrm{~Hz}, 3 \mathrm{H}), 0.90(\mathrm{dd}, J=11.7,8.3 \mathrm{~Hz}$, $1 \mathrm{H}), 0.74-0.66(\mathrm{~m}, 1 \mathrm{H})$.

Ingenol-3-(3,5-Diethylisoxazole-4-Carboxylate) (Ingenol Disoxate, 3) To a solution of ingenol-5,20-acetonide-3-(3,5-diethylisoxazole4-carboxylate) $(4.55 \mathrm{~g}, 8.4 \mathrm{mmol})$ in THF $(36 \mathrm{~mL})$ was added aqueous $4 \mathrm{~N} \mathrm{HCl}(0.72 \mathrm{~mL})$ at room temperature. The mixture was stirred at room temperature for $17 \mathrm{~h}$ and concentrated in vacuo. The residue was purified by chromatography (heptane/ethyl acetate 2:1 to 1:2), giving a product, which was crystallized from ethyl acetate/heptane giving the title compound (3.29 g, 73\%) as white crystals.

${ }^{1} \mathrm{H}$ NMR $\left(600 \mathrm{MHz}\right.$, DMSO- $\left.d_{6}\right) \delta 5.97(\mathrm{~d}$, $J=1.7 \mathrm{~Hz}, 1 \mathrm{H}), 5.91(\mathrm{~s}, 1 \mathrm{H}), 5.88(\mathrm{dd}, J=4.8$, $1.8 \mathrm{~Hz}, 1 \mathrm{H}), 5.45(\mathrm{~d}, J=9.2 \mathrm{~Hz}, 1 \mathrm{H}), 5.43(\mathrm{~s}$, $1 \mathrm{H}), 4.67(\mathrm{t}, J=5.7 \mathrm{~Hz}, 1 \mathrm{H}), 4.26-4.17(\mathrm{~m}, 1 \mathrm{H})$, $3.96(\mathrm{dd}, J=14.1,5.7 \mathrm{~Hz}, 1 \mathrm{H}), 3.89$ (dd, $J=14.2, \quad 5.5 \mathrm{~Hz}, \quad 1 \mathrm{H}), \quad 3.68-3.60 \quad(\mathrm{~m}, \quad 1 \mathrm{H})$, $3.16-3.00(\mathrm{~m}, J=7.6 \mathrm{~Hz}, 2 \mathrm{H}), 2.91-2.76(\mathrm{~m}$, $2 \mathrm{H}), 2.38-2.29(\mathrm{~m}, 1 \mathrm{H}), 1.73(\mathrm{~d}, J=1.5 \mathrm{~Hz}, 3 \mathrm{H})$, 1.68 (ddd, $J=15.5,6.3,3.9 \mathrm{~Hz}, 1 \mathrm{H}), 1.23-1.16$ $(\mathrm{m}, 6 \mathrm{H}), 1.03(\mathrm{~d}, J=4.2 \mathrm{~Hz}, 6 \mathrm{H}), 0.91(\mathrm{~d}$, $J=7.2 \mathrm{~Hz}, 3 \mathrm{H}), 0.78(\mathrm{dd}, J=12.1,8.3 \mathrm{~Hz}, 1 \mathrm{H})$, 0.62 (ddd, $J=9.9,8.2,6.2 \mathrm{~Hz}, 1 \mathrm{H}$ ).

${ }^{13} \mathrm{C}$ NMR (151 MHz, DMSO- $\left.d_{6}\right) \delta$ 205.52, $178.93,163.93,161.46,142.84,136.02$, 132.23, 120.91, 106.97, 85.31, 81.57, 73.66, 71.16, 62.96, 42.47, 37.89, 30.27, 28.09, 23.68, $22.82,22.20,20.21,19.07,16.47,15.45,15.27$, $11.97,11.38$.

Detected " $M+1$ "-mass: 500.26; calculated: 500.26 . 


\section{0-O-(tert-Butyldimethylsilyl)-Ingenol}

(12) Ingenol (2, $25 \mathrm{~g}, 64.6 \mathrm{mmol})$ was dissolved in dichloromethane $(500 \mathrm{~mL})$ and shaken from time to time over molecular sieves (3 $\mathrm{A}, 200 \mathrm{~g}$ ) for $1 \mathrm{~h}$. Filtration and concentration furnished dry ingenol, which was dissolved in dichloromethane $(350 \mathrm{~mL})$ and 2,6-lutidine (11.8 g). The mixture was cooled in an ice-water-salt $(\mathrm{NaCl})$ bath, and a solution of tert-butyldimethylsilyl trifluoromethanesulfonate $(19.6 \mathrm{~g}, 74.3 \mathrm{mmol})$ in dichloromethane $(50 \mathrm{~mL})$ was added during $45 \mathrm{~min}$ (TLC-control: EtOAc/heptane 3:2, $R_{\mathrm{f}}$ $0.75) . \mathrm{HCl}(1.0 \mathrm{~N}, 120 \mathrm{~mL})$ was added to the cold reaction mixture and the aqueous layer was removed. The organic layer was washed consecutively with aqueous saturated $\mathrm{NaHCO}_{3}$ and three times with brine. The organic layer was dried over $\mathrm{Na}_{2} \mathrm{SO}_{4}$ followed by filtration and concentration to produce a yellow oil, which was purified by chromatography (ethyl acetate/heptane 3:7), giving a colorless syrup (19.1 g, 64\%).

${ }^{1} \mathrm{H}$ NMR $\left(300 \mathrm{MHz}, \mathrm{CDCl}_{3}\right) \delta 6.05-5.95(\mathrm{~m}$, $1 \mathrm{H}), 5.90(\mathrm{q}, J=1.6 \mathrm{~Hz}, 1 \mathrm{H}), 4.50(\mathrm{~d}, J=4.3 \mathrm{~Hz}$, $1 \mathrm{H}), 4.32(\mathrm{~d}, J=4.3 \mathrm{~Hz}, 1 \mathrm{H}), 4.28-4.06(\mathrm{~m}, 3 \mathrm{H})$, $4.03(\mathrm{~s}, 1 \mathrm{H}), 3.88-3.82(\mathrm{~m}, 1 \mathrm{H}), 2.64(\mathrm{~d}$, $J=4.5 \mathrm{~Hz}, 1 \mathrm{H}), 2.52-2.38(\mathrm{~m}, 1 \mathrm{H}), 2.32$ (ddd, $J=15.6,9.1,3.1 \mathrm{~Hz}, 1 \mathrm{H}), 1.85(\mathrm{~d}, J=1.5 \mathrm{~Hz}$, $3 \mathrm{H}), 1.75$ (ddd, $J=15.7,6.3,4.8 \mathrm{~Hz}, 1 \mathrm{H}), 1.12$ $(\mathrm{s}, 3 \mathrm{H}), 1.06(\mathrm{~s}, 3 \mathrm{H}), 0.96(\mathrm{~d}, J=7.1 \mathrm{~Hz}, 3 \mathrm{H})$, 0.89 (s, 9H), 0.85-0.9 (m, 1H), 0.69 (td, $J=8.8$, $6.3 \mathrm{~Hz}, 1 \mathrm{H}), 0.08(\mathrm{~d}, J=1.5 \mathrm{~Hz}, 6 \mathrm{H})$.

\section{0-O-(tert-Butyldimethylsilyl)-3-O-(Trimethyl} silyl)-Ingenol (13) 20-O-(tert-Butyldimethyl silyl)-ingenol $(12,19.1 \mathrm{~g}, 39.2 \mathrm{mmol})$ was dissolved in dichloromethane $(250 \mathrm{~mL})$ and 2,6-lutidine (7.14 g, $66.7 \mathrm{mmol})$ was added with stirring. The mixture was cooled in an ice-water-salt $(\mathrm{NaCl})$ bath, and a solution of trimethylsilyl trifluoromethanesulfonate
$(10.0 \mathrm{~g}, \quad 45.10 \mathrm{mmol})$ in dichloromethane $(50 \mathrm{~mL})$ was added during $45 \mathrm{~min}$ (TLC-control: EtOAc/hept 1:9, $R_{\mathrm{f}} 0.40$ for product). $\mathrm{HCl}(1.0 \mathrm{~N}, 85 \mathrm{~mL})$ was added to the cold reaction mixture and the phases were separated. The organic layer was washed consecutively with aqueous saturated $\mathrm{NaHCO}_{3}$ and three times with brine and dried over $\mathrm{Na}_{2} \mathrm{SO}_{4}$ followed by filtration and concentration $(22.4 \mathrm{~g})$. The residue was purified by column chromatography (EtOAc/ hept $=7.5: 92.5$ ), giving the title compound $(8.61 \mathrm{~g})$ as a solid, which was recrystallized from heptane $(50 \mathrm{~mL})$ and left at $-18^{\circ} \mathrm{C}$ overnight. The white solid was filtered off and rinsed twice with $-18^{\circ} \mathrm{C}$ heptane to yield a white solid (6.14 g, 29\%).

${ }^{1} \mathrm{H}$ NMR $\left(300 \mathrm{MHz}, \mathrm{CDCl}_{3}\right) \delta$ 6.05-5.95 (m, $1 \mathrm{H}), 5.87(\mathrm{q}, J=1.5 \mathrm{~Hz}, 1 \mathrm{H}), 4.50(\mathrm{~s}, 1 \mathrm{H}), 4.25$ $(\mathrm{d}, J=15.0 \mathrm{~Hz}, 1 \mathrm{H}), 4.12(\mathrm{~d}, J=15.0 \mathrm{~Hz}, 1 \mathrm{H})$, 4.09-4.00 (m, 1H), 3.72-3.65 (m, 2H), $3.16(\mathrm{~d}$, $J=9.8 \mathrm{~Hz}, 1 \mathrm{H}), 2.42-2.29(\mathrm{~m}, 1 \mathrm{H}), 2.23(\mathrm{ddd}$, $J=15.7,8.3,3.0 \mathrm{~Hz}, 1 \mathrm{H}), 1.83-1.63(\mathrm{~m}, 4 \mathrm{H})$, $1.13(\mathrm{~s}, 3 \mathrm{H}), 1.06(\mathrm{~s}, 3 \mathrm{H}), 1.02-0.80(\mathrm{~m}, 13 \mathrm{H})$, $0.77-0.57(\mathrm{~m}, 1 \mathrm{H}), 0.22(\mathrm{~s}, 9 \mathrm{H}), 0.05(\mathrm{~d}$, $J=4.2 \mathrm{~Hz}, 6 \mathrm{H})$.

\section{0-O-(tert-Butyldimethylsilyl)-3-O-(Trimethyl} silyl)-Ingenol-5-(3,5-Diethylisoxazole-4-Carboxy late) 20-O-(tert-Butyldimethylsilyl)-3-O-(trime thylsilyl)-ingenol $(13,7.58 \mathrm{~g}, 14.2 \mathrm{mmol})$ was dissolved in THF $(57 \mathrm{~mL}), \quad$ and 3,5-diethylisoxazole-4-carbonyl chloride (4, $3.46 \mathrm{~g}, 18.4 \mathrm{mmol}$ ) was added. The mixture was cooled in an ice-water-salt $(\mathrm{NaCl})$ bath, and LiHMDS (17 mL, $1 \mathrm{M}$ in THF, $17.0 \mathrm{mmol}$ ) was added drop wise during $45 \mathrm{~min}$ (TLC-control: EtOAc/heptane 1:9, $R_{\mathrm{f}} 0.40$ for starting material; $R_{\mathrm{f}}=0.45$ for product). tert-Butylmethylether $(150 \mathrm{~mL})$ was added to the reaction mixture, which was cooled to -18 ${ }^{\circ} \mathrm{C}$ and washed quickly with $\mathrm{HCl}(0.5 \mathrm{~N}, 60 \mathrm{~mL})$, 
aqueous $\mathrm{NaHCO}_{3}(60 \mathrm{~mL})$, brine $(3 \times 60 \mathrm{~mL})$ and water $(60 \mathrm{~mL})$ to minimize hydrolysis of the silyl groups. The organic layer was dried over $\mathrm{Na}_{2} \mathrm{SO}_{4}$ followed by filtration and concentration (12.8 g). The crude product was subjected to chromatography on $\mathrm{SiO}_{2}(250 \mathrm{~g})$ eluting with EtOAc/heptane 7.5:92.5, giving the title compound as a colorless syrup $(7.84 \mathrm{~g}$, $81 \%)$, which solidified on standing.

${ }^{1} \mathrm{H} \quad \mathrm{NMR} \quad\left(300 \mathrm{MHz}, \mathrm{CDCl}_{3}\right) \quad \delta \quad 6.21 \quad(\mathrm{~d}$, $J=2.6 \mathrm{~Hz}, 1 \mathrm{H}), 6.02(\mathrm{~d}, J=1.7 \mathrm{~Hz}, 1 \mathrm{H}), 5.57$ (s, 1H), 4.36-4.22 (m, 1H), 4.07-3.93 (m, 2H), 3.88 (s, 1H), 3.78 (d, $J=1.3 \mathrm{~Hz}, 1 \mathrm{H}), 3.18$ (qd, $J=7.6,1.9 \mathrm{~Hz}, 2 \mathrm{H}), 2.97(\mathrm{q}, J=7.5 \mathrm{~Hz}, 2 \mathrm{H})$, $2.54-2.39(\mathrm{~m}, 1 \mathrm{H}), 2.38-2.20(\mathrm{~m}, 1 \mathrm{H}), 1.90-1.77$ (m, 4H), 1.44-1.27 (m, 6H), $1.22(\mathrm{~s}, 3 \mathrm{H}), 1.14(\mathrm{~s}$, $3 \mathrm{H}), 1.00(\mathrm{~d}, J=7.0 \mathrm{~Hz}, 3 \mathrm{H}), 0.97-0.91(\mathrm{~m}, 1 \mathrm{H})$, $0.86(\mathrm{~s}, 9 \mathrm{H}), 0.77(\mathrm{q}, J=8.1 \mathrm{~Hz}, 1 \mathrm{H}), 0.11(\mathrm{~s}$, $6 \mathrm{H}), 0.06(\mathrm{~s}, 9 \mathrm{H})$.

\section{Ingenol-5-(3,5-Diethylisoxazole-4-Carboxylate)}

(8) 20-O-(tert-Butyldimethylsilyl)-3-O-(trime thylsilyl)-ingenol-5-(3,5-diethylisoxazole-4-car boxylate) (7.23 g, $10.5 \mathrm{mmol})$ was dissolved in THF $(120 \mathrm{~mL})$. Water $(6.5 \mathrm{~mL})$ was added and the mixture was cooled in an ice-water bath. A cold solution of methanesulfonic acid $(8.1 \mathrm{~g}$, $84.3 \mathrm{mmol})$ in water $(6.5 \mathrm{~mL})$ was added drop wise over $15 \mathrm{~min}$, and the biphasic reaction mixture was stirred at room temperature for a total of $100 \mathrm{~min}$ (TLC-control: EtOAc/ heptane $=50: 50, \quad R_{\mathrm{f}} 0.95$ for the starting material, $R_{\mathrm{f}} \quad 0.55$ for the product). tert-Butylmethylether $(400 \mathrm{~mL})$ was added to the reaction mixture, and the organic layer was washed consecutively with water $(4 \times 100 \mathrm{~mL})$, aqueous $\mathrm{NaHCO}_{3} \quad(100 \mathrm{~mL})$ and water $(3 \times 100 \mathrm{~mL})$ followed by drying over $\mathrm{Na}_{2} \mathrm{SO}_{4}$. Concentration resulted in colorless syrup, which solidified. The crude product was subjected to chromatography on $\mathrm{SiO}_{2}(250 \mathrm{~g})$ eluting with EtOAc/heptane $=37: 63\left(R_{\mathrm{f}} 0.33\right)$, giving $4.5 \mathrm{~g}$ of the title product as a white solid (85\%).

${ }^{1} \mathrm{H}$ NMR $\left(600 \mathrm{MHz}, \mathrm{CDCl}_{3}\right) \delta 6.32-6.10(\mathrm{~m}$, $1 \mathrm{H}), 6.00-5.86(\mathrm{~m}, 1 \mathrm{H}), 5.48(\mathrm{~s}, 1 \mathrm{H}), 4.32-4.23$ (m, 1H), $4.09(\mathrm{dd}, J=12.2,5.0 \mathrm{~Hz}, 1 \mathrm{H}), 3.91(\mathrm{~d}$, $J=13.6,1 \mathrm{H}), 3.86(\mathrm{~d}, J=13.6,1 \mathrm{H}), 3.84-3.74$ $(\mathrm{m}, 2 \mathrm{H}), 3.09(\mathrm{q}, J=7.6 \mathrm{~Hz}, 2 \mathrm{H}), 2.81(\mathrm{qd}$, $J=7.6,4.6 \mathrm{~Hz}, 2 \mathrm{H}), 2.46-2.35(\mathrm{~m}, 1 \mathrm{H}), 2.30$ (ddd, $J=15.7,8.5,3.1 \mathrm{~Hz}, 1 \mathrm{H}), 1.93(\mathrm{~s}, 1 \mathrm{H})$, $1.92(\mathrm{~s}, 3 \mathrm{H}), 1.76(\mathrm{dt}, J=15.7,5.8 \mathrm{~Hz}, 1 \mathrm{H}), 1.27$ $(\mathrm{t}, J=7.6 \mathrm{~Hz}, 3 \mathrm{H}), 1.21(\mathrm{t}, J=7.4 \mathrm{~Hz}, 3 \mathrm{H}), 1.13$ $(\mathrm{s}, 3 \mathrm{H}), 1.05(\mathrm{~s}, 3 \mathrm{H}), 1.00-0.94(\mathrm{~m}, 4 \mathrm{H}), 0.71(\mathrm{td}$, $J=8.4,6.3 \mathrm{~Hz}, 1 \mathrm{H})$.

Detected " $M+1$ "-mass: 500.26; calculated: 500.26 .

\section{Ingenol-20-(3,5-Diethylisoxazole-4-Carboxylate)}

(9) To a solution of ingenol-3-(3,5-diethyl isoxazole-4-carboxylate) $(3,2.0 \mathrm{~g}, 4.0 \mathrm{mmol})$ in isopropanol $(100 \mathrm{~mL})$ was added diisopropylethylamine $(16.5 \mathrm{~mL})$ at room temperature. The obtained solution was stirred at $65{ }^{\circ} \mathrm{C}$ for 35 days and poured into $100 \mathrm{~mL}$ of tert-butylmethylether. The obtained solution was washed separately with aqueous $\mathrm{HCl}(1 \mathrm{~N}$, $2 \times 50 \mathrm{~mL})$, saturated aqueous $\mathrm{NaHCO}_{3}(50 \mathrm{~mL})$ and water $(50 \mathrm{~mL})$, and concentrated in vacuo. The oily residue was purified by chromatography (ethyl acetate/heptane $1: 4 \rightarrow 1: 1$ ), giving $0.46 \mathrm{~g}$ of product (23\% yield) as a foam.

${ }^{1} \mathrm{H} \quad \mathrm{NMR} \quad\left(600 \mathrm{MHz}, \mathrm{CDCl}_{3}\right) \quad \delta \quad 6.16(\mathrm{dd}$, $J=4.8,1.5 \mathrm{~Hz}, 1 \mathrm{H}), 5.99(\mathrm{q}, J=1.6 \mathrm{~Hz}, 1 \mathrm{H})$, $4.94(\mathrm{~d}, J=11.9 \mathrm{~Hz}, 1 \mathrm{H}), 4.66(\mathrm{~d}, J=12.0 \mathrm{~Hz}$, $1 \mathrm{H}), 4.44(\mathrm{~d}, J=6.7 \mathrm{~Hz}, 1 \mathrm{H}), 4.17(\mathrm{~d}, J=1.1 \mathrm{~Hz}$, $1 \mathrm{H}), \quad 4.15-4.05(\mathrm{~m}, 1 \mathrm{H}), 3.70(\mathrm{dd}, J=11.6$, $1.7 \mathrm{~Hz}, 1 \mathrm{H}), 3.01(\mathrm{q}, J=7.6 \mathrm{~Hz}, 2 \mathrm{H}), 2.90(\mathrm{~d}$, $J=11.4 \mathrm{~Hz}, 1 \mathrm{H}), 2.82(\mathrm{q}, J=7.4 \mathrm{~Hz}, 2 \mathrm{H}), 2.66$ $(\mathrm{d}, J=6.9 \mathrm{~Hz}, 1 \mathrm{H}), 2.42-2.21(\mathrm{~m}, 2 \mathrm{H}), 1.84(\mathrm{~d}$, $J=1.6 \mathrm{~Hz}, 3 \mathrm{H}), 1.78(\mathrm{dt}, J=16.3,5.5 \mathrm{~Hz}, 1 \mathrm{H})$, 1.32-1.19 (m, 6H), $1.11(\mathrm{~s}, 3 \mathrm{H}), 1.07(\mathrm{~s}, 3 \mathrm{H})$, $0.98(\mathrm{~d}, J=7.0 \mathrm{~Hz}, 3 \mathrm{H}), 0.95(\mathrm{dd}, J=11.8$, $8.4 \mathrm{~Hz}, 1 \mathrm{H}), 0.72(\mathrm{td}, J=8.7,6.3 \mathrm{~Hz}, 1 \mathrm{H})$. 
Detected " $M+1$ "-mass: 500.26; calculated: 500.26 .

\section{Partition and Distribution Coefficients}

The partition coefficients $S+\log P(\mathrm{pH}$ 7.4) were calculated with MedChem Designer ${ }^{\mathrm{TM}}$ version 2.0.0.34 (Simulations Plus, Inc.). The distribution coefficients $(\log D)$ at $\mathrm{pH} 3$ were determined by the shake flask method by equilibrating the compounds in equal amounts of octanol and citrate buffer for $24 \mathrm{~h}$. Due to the lipophilic character of the compounds in combination with their relatively weak UV response the quantification of the compounds in the buffer phase is associated with some degree of uncertainty.

\section{Compound Stability}

\section{Stability in Hydroalcoholic Gel}

The marketed ingenol mebutate gel and ingenol disoxate hydroalcoholic gel of GMP quality were stored in $1 \mathrm{~mL}$ laminated tubes with screw caps. Concentration and impurity determinations for ingenol mebutate (triplicates) and ingenol disoxate (duplicates) were performed on Waters UHPLC equipment using external reference standards of ingenol mebutate (1) and ingenol disoxate (3), respectively.

Determination of ingenol mebutate was performed using a reverse phase UHPLC method with an Acquity UPLC BEH C18, $100 \times 2.1 \mathrm{~mm}$, sub $2 \mu \mathrm{m}$ column and a mobile phase gradient of $0.1 \%$ phosphoric acid and acetonitrile, from $50 \% \mathrm{v} / \mathrm{v}$ to $90 \% \mathrm{v} / \mathrm{v}$ acetonitrile, and UV detection at $212 \mathrm{~nm}$.

Ingenol disoxate was analyzed analogously using a reverse phase UHPLC method with an Acquity HSS C18, $150 \times 2.1 \mathrm{~mm}$, sub $2 \mu \mathrm{m}$ column and the same mobile phases from $50 \%$ $\mathrm{v} / \mathrm{v}$ to $95 \% \mathrm{v} / \mathrm{v}$ acetonitrile, and UV detection at $220 \mathrm{~nm}$.

Preparation of Ingenol Disoxate Hydroalcoholic Gel An aqueous citrate buffer with $\mathrm{pH} 2.8$ was prepared by mixing water, citric acid monohydrate and sodium citrate dihydrate in the main production vessel. Ingenol disoxate (3) was dissolved in benzyl alcohol in a secondary vessel and isopropanol was added. The ingenol disoxate alcoholic solution was added to the aqueous buffer at a temperature below $15^{\circ} \mathrm{C}$. The gelling agent was slowly added to the hydroalcoholic solution and mixed until a homogeneous gel was formed.

Preparation of the Analytical Samples Ingenol mebutate gel: a mixture of the marketed product $(2.5 \mathrm{~g})$ and $20 \mathrm{~mL} 0.1 \%$ phosphoric acid/acetonitrile 10:90\% v/v was vortexed for $1 \mathrm{~min}$ in a $25 \mathrm{~mL}$ flask and then diluted to volume with the same solvent. Two milliliters from the clear top layer was mixed with $3.3 \mathrm{~mL}$ of acetonitrile and sufficient $0.1 \%$ phosphoric acid to a total volume of $10.0 \mathrm{~mL}$.

Ingenol disoxate hydroalcoholic gel: a mixture of ingenol disoxate hydroalcoholic gel $(0.4 \mathrm{~g})$ and $5 \mathrm{~mL} \quad 0.1 \%$ phosphoric acid/ acetonitrile $50: 50 \% \mathrm{v} / \mathrm{v}$ was vortexed vigorously for $30 \mathrm{~s}$ to disperse the gel, and diluted to a total volume of $10.0 \mathrm{~mL}$ with the same solvent.

\section{Stability in Phosphate Buffer}

The stability of ingenol mebutate (1), ingenol disoxate (3) and the 5- and 20-isomers of ingenol disoxate $(8,9)$ was evaluated in phosphate buffer $(0.067 \mathrm{M} ; \quad$ pH 7.4$) \quad$ with $\quad 30 \%$ co-solvent (acetonitrile). An initial compound concentration of $100 \mu \mathrm{M}$ was used and the stability was monitored at $37^{\circ} \mathrm{C}$ for a 24 -h period on a Waters LCT Premier XE TOF instrument with Acquity UPLC. The products were separated using a reverse 
phase UPLC method with an Acquity HSS C18, $50 \times 2.1 \mathrm{~mm}, 1.8 \mu \mathrm{m}$ column and a linear gradient of $10 \mathrm{mM}$ ammonium acetate and acetonitrile (both with $0.1 \%$ formic acid) from $1 \% \mathrm{v} / \mathrm{v}$ to $95 \%$ $\mathrm{v} / \mathrm{v}$ acetonitrile in $2 \mathrm{~min}$ with a $0.7 \mathrm{~mL} / \mathrm{min}$ flow rate. The relative recovery of the analytes was determined by UV detection (240-400 nm) and the identity of the degradation products was confirmed using positive mode MS electrospray detection and external reference standards.

\section{Acute Cancer Cell Cytotoxicity}

HeLa cells (human cervix carcinoma, ATCC \#CCL-2), B16-F10 cells (mouse melanoma, ATCC \#6475; American Type Culture Collection, Manassas, VA, USA), or HSC-5 cells (human SCC, JCRB1016, JCRB Cell Bank, Japan) were seeded at $4 \times 10^{3}$ cells/well and incubated overnight in MEM containing $10 \%$ FBS at $37^{\circ} \mathrm{C}$ in humidified air/ $\mathrm{CO}_{2}(95 \% / 5 \%)$. Cells were treated with increasing concentrations of test compound for $30 \mathrm{~min}$ at $37^{\circ} \mathrm{C}$. Mitochondrial activity as a sign of cell viability was determined subsequently by incubation with the resazurin-based dye formulation PrestoBlue ${ }^{\circledR}$ (Invitrogen) for $30 \mathrm{~min}$. Active mitochondria convert PrestoBlue to a fluorescent dye which reflect cell viability and can be quantified at $615 \mathrm{~nm}$ using an EnVision plate reader. Complete loss of mitochondrial activity was taken as a measure of cell death. Lethal concentration $\left(\mathrm{LC}_{50}\right)$ was calculated as the concentrations of ingenol disoxate or ingenol mebutate producing 50\% loss of mitochondrial activity.

\section{Keratinocyte Proliferation, Viability and Caspase 3/7 Activation}

Human adult log-phase primary epidermal keratinocytes (Invitrogen) were subcultured in 96-well plates at $4 \times 10^{3}$ cells/well in $100 \mu \mathrm{L}$ serum-free EpiLife medium with HKGS supplement (Invitrogen) overnight at $37^{\circ} \mathrm{C}$ in humidified air/ $\mathrm{CO}_{2}(95 \% / 5 \%)$ before exposure to titrated test compound for $72 \mathrm{~h}$. Subsequently, cell proliferation was assessed by measuring DNA content as a reliable surrogate of cell number using the homogeneous CyQUANT $^{\circledR}$ Direct nucleic acid stain kit (Invitrogen) according to manufacturer's instructions. Cell viability and caspase 3/7 activation was assessed in separate assay plates by the ApoTox-Glo ${ }^{\mathrm{TM}}$ Triplex Assay (Promega) according to the protocol supplied with the kit by 1) measuring the proteolytic activity of housekeeping aminopeptidases, which become labile following plasma membrane disintegration and 2) measuring cleavage of a luminogenic caspase 3/7 substrate. Percentage inhibition (all read-outs) was calculated by normalizing to the effect of a cytotoxic concentration $(1 \mu \mathrm{M})$ of the antibiotic geldanamycin.

\section{Real-Time Quantitative PCR}

RNA was extracted from monolayers of primary human epidermal keratinocytes (Invitrogen) incubated in high calcium $\left(1.8 \mathrm{mM} \mathrm{CaCl}_{2}\right)$ EpiLife medium or exposed to $100 \mathrm{nM}$ ingenol disoxate or $100 \mathrm{nM}$ ingenol mebutate in low calcium $\left(0.06 \mathrm{mM} \mathrm{CaCl}_{2}\right)$ EpiLife medium for $72 \mathrm{~h}$. When indicated cells were pre-incubated with $500 \mathrm{nM}$ bisindolylmaleimide I for $30 \mathrm{~min}$ prior to exposure to $100 \mathrm{nM}$ ingenol disoxate or $100 \mathrm{nM}$ ingenol mebutate. Following cDNA synthesis, relative gene expression levels of keratin 1 (KRT1), keratin 10 (KRT 10), involucrin (INVL), transglutaminase-1 (TGM1), filaggrin (FLG), and loricrin (LOR) were determined by real-time quantitative PCR (qPCR) using validated gene expression assays 
(Applied Biosystems) and ABI PRISM ${ }^{\circledR} 7900 \mathrm{HT}$ sequence detection system. A panel of four reference genes (PPIA, RPLPO, GAPDH, TBP) was used for qPCR data normalization.

\section{Neutrophil Granulocyte Respiratory Burst}

Neutrophil granulocytes were isolated and purified from fresh buffy coats by sequential sedimentation, Lymphoprep ${ }^{\mathrm{TM}}$ (STEMCELL Technologies) density centrifugation and hypertonic lysis of contaminating erythrocytes. Cells were resuspended in Dulbecco's PBS $\left(\mathrm{Ca}^{2+}\right.$ and $\mathrm{Mg}^{2+}$-free) and the concentration adjusted to $2.5 \times 10^{5}$ cells/well (96-well plates) in HBSS (containing $\mathrm{Ca}^{2+}$ and $\mathrm{Mg}^{2+}$ ) supplemented with $0.1 \%$ bovine serum albumin and $5 \mathrm{mM}$ glucose just prior to assay initiation. Cells were incubated with titrated ingenol disoxate or ingenol mebutate, premixed with $10 \mu \mathrm{M}$ hydroethidine for $40 \mathrm{~min}$ at ambient temperature. The neutrophil granulocyte respiratory burst was quantified by measuring fluorescence, expressed in relative light units (RLU), at $579 \mathrm{~nm}$ (ex $485 \mathrm{~nm}$ ) using an EnVision plate reader. Effective concentration $\left(\mathrm{EC}_{50}\right)$ was calculated as the concentration of test compound producing $50 \%$ of the maximum effect achieved by ingenol mebutate.

\section{Keratinocyte IL-8 Release}

Human adult log-phase primary epidermal keratinocytes (Invitrogen) were seeded into 96-well plates at $1 \times 10^{4}$ cells/well in serum-free EpiLife medium with HKGS supplement (Invitrogen) overnight at $37^{\circ} \mathrm{C}$ in humidified air/ $\mathrm{CO}_{2}(95 \% / 5 \%)$ before exposure to titrated test compound for $6 \mathrm{~h}$. Secreted IL-8 levels were quantified using Meso Scale Discovery 4-spot cytokine plates, or based on homogeneous time-resolved fluorescence
(Human IL-8 HTRF $^{\circledR}$ kit, CisBio). EC EO $_{50}$ was calculated as described for neutrophil granulocytes.

\section{PKC Activation}

The modulatory effects on classical $(\alpha, \beta I I, \gamma)$ and novel PKC isoforms $(\delta, \varepsilon, \eta, \theta)$ were tested in the KinaseProfiler $^{\mathrm{TM}}$ assay (Millipore) using $0.01-0.05 \mathrm{mg} / \mathrm{mL}$ phosphatidylserine in the absence of diacylglycerol to allow for observations of any stimulatory effects. The compounds were serially diluted, at semi-logarithmic intervals, for twelve points starting from $1 \mathrm{nM}$ to $10 \mu \mathrm{M}$. Calcium was included in assays with the classical PKC isoforms, but not in assays with the novel PKC isoforms. Assays were started by the addition of ATP and run for $40 \mathrm{~min}$ at room temperature before quantification of phosphorylated PKC substrate levels using liquid scintillation counting. Data points for the $\mathrm{EC}_{50}$ determinations were performed in duplicates. The 3-, 5- and 20-isomers of both ingenol mebutate and ingenol disoxate were tested head to head against PKC $\alpha$, PKC $\beta I I$ and PKC $\delta$ in a separate study. For measurements on the two classical PKC isoforms the phosphatidylserine concentration was reduced to $0.005 \mathrm{mg} / \mathrm{mL}$, to increase the assay window.

\section{B16 Melanoma Mouse Model}

Murine B16 melanoma cells $\left(5 \times 10^{5}\right)$ were injected intradermally in the flank of 8-10 weeks old female C57BL/6 J mice purchased from Taconic. Three days after B16 injection when visible tumor nodules had formed, the tumor size was measured with a digital caliper. The tumor volume was calculated as $0.5 \times \mathrm{ld} \times \mathrm{pd}$ (ld: longest diameter; pd: perpendicular diameter) and 
mice were distributed into cohorts of 8-10 mice with an equal tumor volume between groups. Four days after tumor cell inoculation mice were treated topically for two consecutive days with $20 \mu \mathrm{L}$ of the test compound formulated at $0.1 \%$ in a hydroalcoholic gel (vehicle of marketed ingenol mebutate). The treatment area covering the tumor site was approximately $2 \mathrm{~cm}^{2}$. Tumor growth was monitored daily until day 90 or until tumor volume exceeded $250 \mathrm{~mm}^{3}$ or the tumor was ulcerating. A cut-off site of $250 \mathrm{~mm}^{3}$ was chosen to limit animal suffering, as the B16 tumors have a tendency to ulcerate when growing larger. This model was covered by animal ethics permission no 2012_15_2934_00368 issued by The Animal Experiments Inspectorate in Denmark.

\section{Local Skin Reaction in Guinea Pigs}

A $\quad 0.015 \%$ and $0.05 \%$ hydroalcoholic gel formulation of either ingenol disoxate or ingenol mebutate or vehicle alone was dosed topically by applying $10 \mu \mathrm{L}$ formulation on five $2 \mathrm{~cm}^{2}$ fields (one field per test condition) on the flanks of each of 7 IAF hairless female guinea pigs $\mathrm{Crl}: \mathrm{HA}-\mathrm{Hr}^{\mathrm{Hr}}$. Animals were monitored over a period of up to 4 days and the local skin reaction (LSR) was scored on a daily basis. The LSR is a composite score of the individual scores of the following responses: edema, erythema, ulceration and subcutaneous bleeding. Four of the animals were terminated $24 \mathrm{~h}$ after dosing, and $4 \mathrm{~mm}$ punch biopsies taken from each treatment site were formalin fixed, paraffin embedded and cut into $3 \mu \mathrm{m}$ tissue sections, which were analyzed following hematoxylin/ eosin staining. This model was covered by animal ethics permission no 2012_15_2934_00067 issued by The Animal Experiments Inspectorate in Denmark.

\section{UV-Induced Skin Cancer Mouse Model}

Hairless SKH1 mice (Crl:SKH1-Hr ${ }^{h r}$ ) were irradiated three times weekly for 10 weeks with a minimum erythema dose of UV light using two parallel mounted Philips TL 40 W/12 RS SLV fluorescent tubes [54\% output in UVB (280-315 nm) and 46\% in UVA (315-400 nm)]. The mice received a dose of approximately $1.14 \mathrm{~J} / \mathrm{m}^{2}$ per irradiation which led to appearance of the first skin tumors starting at week 11 with further tumors appearing over the subsequent months. Skin tumors were treated topically for two consecutive days with $2.5 \mu \mathrm{L}$ ingenol mebutate $(0.05 \%$ or $0.1 \%)$ or ingenol disoxate $(0.1 \%)$ in hydroalcoholic gel formulation (vehicle of marketed ingenol mebutate) per tumor per treatment. Treatment of tumors was done individually as they appeared starting 1-2 weeks after their appearance and marked by tattoo to keep track of their location. The tumors were typically 1-2 $\mathrm{mm}$ in diameter at treatment start. Treatment success (i.e., tumor clearance) or failure was assessed 2 weeks after treatment, at which time point the skin had recovered from the treatment with the compounds. Cleared tumors were subsequently inspected weekly for recurrence for up to 5 weeks. This model was covered by animal ethics permission no 2013-15-2934-00905 issued by The Animal Experiments Inspectorate in Denmark.

\section{Skin Penetration in a Franz Chamber Diffusion Set-Up}

Full thickness human skin was sourced from abdominal surgery from the Department of Plastic Surgery, Herlev Hospital, Denmark. The skin was collected after written informed consent from the donor and used to assess ingenol disoxate and ingenol mebutate skin 
penetration using vertical glass diffusion cells from PermeGear, Inc. incorporating two consoles of nine diffusion cells/treatment. The skin was placed over a support with an orifice of $2 \mathrm{~cm}$ in diameter and the cells placed in a cell warmer connected with a Haake ${ }^{\circledR}$-DC10 (Thermo Scientific) circulating bath to maintain membrane surface temperature at $32{ }^{\circ} \mathrm{C}$. The Franz cell receptor chamber was filled with EpiLife medium complemented with human keratinocyte growth supplement and placed on a magnetic stirrer. $0.1 \%$ ingenol disoxate or ingenol mebutate in hydroalcoholic gel formulations were applied to each Franz cell. Following $21 \mathrm{~h}$ incubation, excess formulation on the skin surface was removed and the skin was tape-stripped using $12 \times$ D-Squame tape to remove the stratum corneum. An $8 \mathrm{~mm}$ biopsy was sampled for compound analysis and heat separated into epidermis and dermis. To eliminate any contribution of apical to basolateral smearing of drug into the dermis during sampling a second $4 \mathrm{~mm}$ biopsy was isolated from the dermis samples. Skin drug concentrations were determined by a procedure involving homogenization of biopsies, extraction in acetonitrile, followed by analysis on liquid chromatography and tandem mass spectrometry (LC-MS/MS), using internal standards for quantification. The limit of quantification (LOQ) was $3 \mathrm{ng} /$ biopsy of both analytes.

\section{Statistical Analysis}

Statistical significance was evaluated using two-sample unpaired $t$ test comparing the averages obtained in separate experiments. Comparison of skin exposure levels in the Franz chamber diffusion set-up was performed using the Mann-Whitney $U$ test. Statistical analysis was performed using GraphPad Prism 6 (GraphPad Software, Inc. La Jolla, CA, USA).

\section{RESULTS}

\section{Regiocontrolled Syntheses of Ingenol Esters}

Following our previously published stereoconservative semisynthetic method, ingenol mebutate (ingenol 3-angelate, 1) was prepared from ingenol (2) without concomitant isomerization of the angelate (Z-form) to the corresponding tiglate (E-form) [11]. Ingenol disoxate (3) was prepared by reacting the 5,20-acetonide protected ingenol derivative (5) with 3,5-diethylisoxazole-4-carbonyl chloride (4) with 4-dimethylaminopyridine as catalyst under microwave heating in an overall yield of 69\% after deprotection (Fig. 2).

The potential rearrangement product $\mathbf{8}$ (Table 1) was synthesized by masking the 20and 3-postions with $t$-butyldimethylsilyl (12) and trimethylsilyl (13) groups, respectively, prior to acylation with 3,5-diethylisoxazole-4-carbonyl chloride (4) followed by deprotection.

The other more stable 20-isomer 9 was made in a modest yield of $23 \%$ by a base-catalyzed rearrangement of ingenol disoxate in isopropanol.

\section{Ingenol Mebutate and Ingenol Disoxate Have Comparable Lipophilicities}

The distribution coefficients $(\log D)$ at $\mathrm{pH} 3$ were determined by the shake flask method to be 3.5 for ingenol mebutate and 3.9 for ingenol disoxate. Due to the lipophilic character of the compounds in combination with their relatively weak UV response the quantification of the compounds in the buffer phase is associated with some degree of uncertainty. 


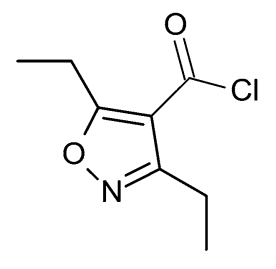

(4)

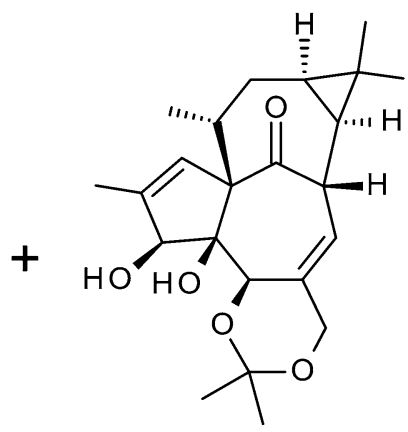

(5)
Fig. 2 Synthesis of ingenol disoxate from ingenol-5,20-acetonide (5). Step A: microwave assisted coupling with DMAP/DIPEA catalysis in acetonitrile,

The partition coefficients $(S+\log P)$ were calculated to be 2.35 for ingenol mebutate and 2.24 for LEO ingenol disoxate.

\section{Ingenol Disoxate is a Chemically Stable Ingenol Ester}

The stability of ingenol disoxate hydroalcoholic gel $0.05 \%$ has been investigated at long term and accelerated storage conditions, $5{ }^{\circ} \mathrm{C}$ and $25^{\circ} \mathrm{C} / 60 \% \mathrm{RH}$, respectively (Table 2 ).

The concentration determinations of ingenol disoxate, calculated as percentage of label claim, are listed together with data for related impurities and $\mathrm{pH}$ of the gel in Table 2. Results show that the primary degradation product for ingenol disoxate in hydroalcoholic gel is $\mathbf{8}$ caused by acyl migration by the side chain from the 3- to the 5-position (Table 2). Measurements of the amounts of ingenol disoxate show minimal fluctuations during the 18 months storage of the ingenol disoxate hydroalcoholic gel at $5{ }^{\circ} \mathrm{C}$. The accelerated conditions at $25^{\circ} \mathrm{C} / 60 \% \mathrm{RH}$ led to a decrease of $2.6 \%$ of label claim of ingenol disoxate after 6 months storage. The content of the primary

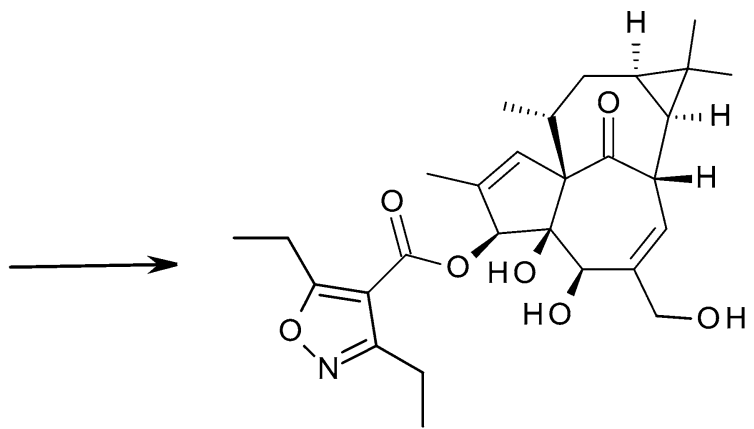

Ingenol disoxate (3)

$150{ }^{\circ} \mathrm{C}$, 94\% yield. Step B: deprotection in aqueous hydrochloric acid at room temperature, $69 \%$ yield

degradation product 8 increased from $0.4 \%$ area to $2.0 \%$ area after 6 months storage at $25{ }^{\circ} \mathrm{C} /$ $60 \%$ RH. Some new minor impurities also started to appear.

The stability of the marketed $0.05 \%$ ingenol mebutate gel has also been investigated at long term and accelerated storage conditions, $5{ }^{\circ} \mathrm{C}$ and $25^{\circ} \mathrm{C} / 60 \% \mathrm{RH}$, respectively (Table 2 ). Results show that the primary degradation product in the ingenol mebutate gel is PEP 015 (6), as a result of acyl migration (Table 2). The measured amounts of ingenol mebutate show some fluctuation and a tendency to decrease over time when the gel is stored at $5{ }^{\circ} \mathrm{C}$. The amount of ingenol mebutate in the gel shows a decrease of $8.0 \%$ of label claim after 6 months storage at $25^{\circ} \mathrm{C} / 60 \% \mathrm{RH}$. The content of the primary degradation product 6 increased from $0.2 \%$ area to $5.1 \%$ area after 6 months storage at $25{ }^{\circ} \mathrm{C} / 60 \% \mathrm{RH}$.

To investigate the stability under conditions of further biological relevance we subjected ingenol disoxate to a test over $24 \mathrm{~h}$ in aqueous buffer ( $\mathrm{pH} 7.4$ ) at $37^{\circ} \mathrm{C}$, while quantifying the relative amounts of ingenol disoxate and its potential rearrangement 
Table 2 Superior stability of ingenol disoxate in a clinically relevant formulation

\begin{tabular}{|c|c|c|c|c|c|c|}
\hline \multirow{2}{*}{$\begin{array}{l}\text { Storage temperature } \\
5^{\circ} \mathrm{C}\end{array}$} & \multicolumn{6}{|c|}{ Storage time in months } \\
\hline & $\overline{\text { Start }}$ & 3 & 6 & 12 & 18 & 24 \\
\hline \multicolumn{7}{|c|}{ Concentration of (\% of label claim) } \\
\hline Ingenol disoxate & 100.0 & 100.9 & 99.4 & 99.1 & 99.0 & - \\
\hline Ingenol mebutate & 98.2 & 97.8 & 95.6 & 95.2 & - & 96.0 \\
\hline \multicolumn{7}{|c|}{ Largest single impurity for (area \%) } \\
\hline Ingenol disoxate $^{\mathrm{a}}$ & 0.4 & 0.4 & 0.5 & 0.6 & 0.6 & - \\
\hline Ingenol mebutate $^{\mathrm{b}}$ & 0.2 & 0.5 & 0.7 & 1.1 & - & 2.4 \\
\hline \multicolumn{7}{|c|}{ Total impurities for (area \%) } \\
\hline Ingenol disoxate & 1.2 & 1.2 & 1.3 & 1.4 & 1.5 & - \\
\hline Ingenol mebutate & 0.8 & 1.7 & 1.2 & 1.8 & - & 3.1 \\
\hline \multicolumn{2}{|l|}{ Storage temperature } & \multicolumn{5}{|c|}{ Storage time in months } \\
\hline $25^{\circ} \mathrm{C} / 60 \% \mathrm{RH}$ & & & 1 & & 3 & 6 \\
\hline \multicolumn{7}{|c|}{ Concentration of (\% of label claim) } \\
\hline Ingenol disoxate & & & 99.6 & & 98.9 & 97.4 \\
\hline Ingenol mebutate & & & 97.0 & & 94.3 & 90.2 \\
\hline \multicolumn{7}{|c|}{ Largest single impurity for (area \%) } \\
\hline Ingenol disoxate $^{a}$ & & & 0.7 & & 1.2 & 2.0 \\
\hline Ingenol mebutate $^{\mathrm{b}}$ & & & 0.8 & & 2.4 & 5.1 \\
\hline \multicolumn{7}{|c|}{ Total impurities for (area \%) } \\
\hline Ingenol disoxate & & & 1.5 & & 2.2 & 3.0 \\
\hline Ingenol mebutate & & & 1.5 & & 3.5 & 5.9 \\
\hline
\end{tabular}

Long-term stability of the marketed ingenol mebutate gel (0.05\% w/v; pH 3.6-3.8) and ingenol disoxate in hydroalcoholic gel $(0.05 \% \mathrm{w} / \mathrm{v}$; $\mathrm{pH} 3.4-3.5)$ was investigated at $5{ }^{\circ} \mathrm{C}$ and at accelerated storage conditions $\left(25^{\circ} \mathrm{C} / 60 \%\right.$ relative humidity). The concentration determinations of ingenol disoxate and ingenol mebutate, calculated as percentage of label claim, are listed together with relative levels of impurities

a, b Denote the 5-isomer re-arrangement products of ingenol disoxate (8) and ingenol mebutate (6), respectively

products 8 (5-isomer) and 9 (20-isomer; Fig. 3a).

Ingenol disoxate (3) was slowly converted to the more stable inactive 20-isomer (9), which amounted to $1 \%$ and $25 \%$ at 2 and $24 \mathrm{~h}$, respectively. The intermediate 5-isomer (8) remained at low $(<3 \%)$ and relatively constant levels during the entire monitoring period. The corresponding study of ingenol mebutate stability showed a rapid conversion into the 5-isomer (6), which gradually rearranged into the thermodynamically more stable and inactive 20-isomer (7; Fig. 3b). Following 2and 24-h incubation, the remaining levels of 

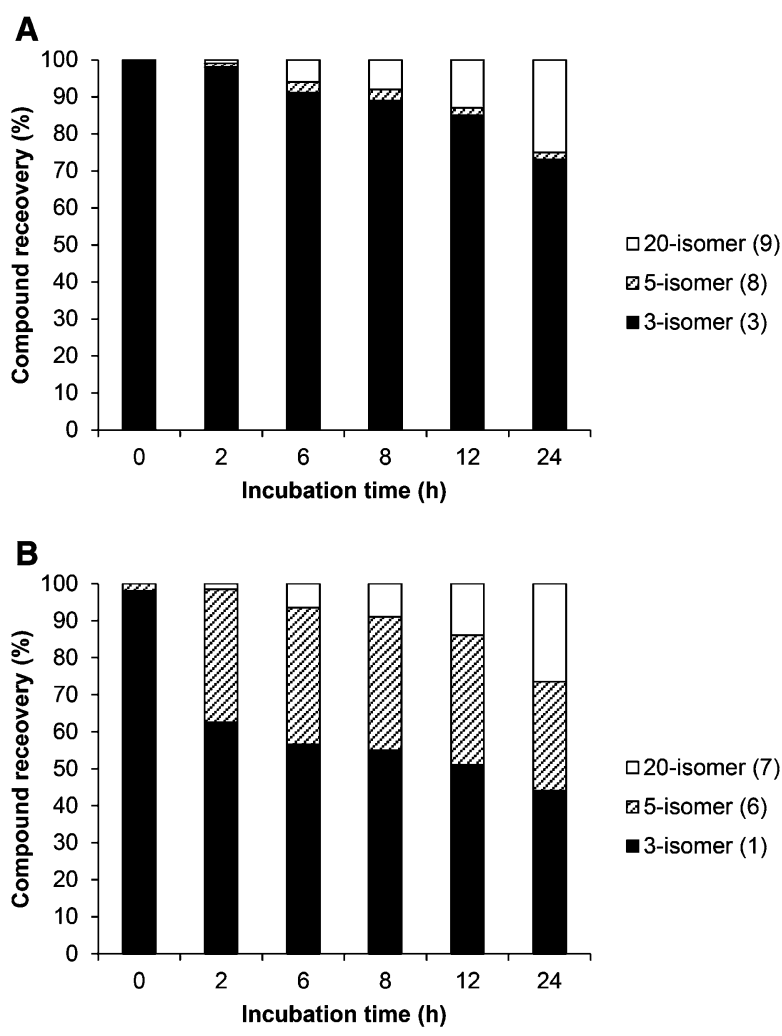

Fig. 3 Superior stability of ingenol disoxate in phosphate buffer. Recovery of ingenol disoxate (a) and ingenol mebutate (b) incubated in $0.067 \mathrm{M}$ phosphate buffer $(\mathrm{pH} 7.4)$ at $37^{\circ} \mathrm{C}$ for the indicated time was analyzed together with quantification of their corresponding rearrangement products. Ingenol derivative numbers (Table 1) are indicated in parentheses after each ingenol derivative isomer

ingenol mebutate amounted to approximately $60 \%$ and $45 \%$, respectively. The conclusions regarding the relative stabilities were further supported by studies of the 20-isomer of ingenol disoxate (9) being the thermodynamically more stable product as it did not change over time (Fig. S1A in the supplementary material).

Furthermore, the 5-ester (8) represents a transition product as it gradually equilibrated to a mixture of mainly the 20 -isomer (86-88\%) and comparable low amounts of the 3- and 5-isomers (Fig. S1B in the supplementary material).

\section{Acute Induction of Cytotoxicity in Epithelial Cancer Cell Lines by Ingenol Disoxate}

Acute cytotoxicity is a hallmark of ingenol mebutate treatment in a large number of solid tumor lines including epithelial and skin carcinoma cells. Previous studies have demonstrated almost equal cytotoxic potency of ingenol mebutate against a variety of cell lines suggesting that the mechanism of cytotoxicity is similar $[13,20]$. We sought to investigate if the cytotoxic potency was maintained by the novel ingenol mebutate analogue ingenol disoxate by analyzing acute cytotoxicity in the human epithelial cervix carcinoma cell line, HeLa, and in the human SCC line, HSC-5. The concentration required to decrease cell viability by $50 \%$ was significantly (twofold) lower for ingenol disoxate relative to ingenol mebutate demonstrating a significantly higher cytotoxic potency of ingenol disoxate (Fig. 4).

\section{Ingenol Disoxate is a Strong Activator of Classical and Novel PKC Isoforms}

PKC is a family of serine/threonine kinases which can be divided into subgroups based on sensitivity to calcium ions and lipid modulators $[21,22]$. Several findings suggest that part of the activity of ingenol mebutate involves spatio-temporal activation of both novel and classical PKC isoforms, leading to a pro-inflammatory response that may contribute to clinical efficacy of ingenol mebutate $[14,23]$. Epidermal keratinocytes express both classical $(\alpha)$ and novel $(\delta, \eta, \varepsilon)$ PKC isoforms [24]. Ingenol disoxate was profiled against selected PKC isoforms representing both subgroups in a biochemical radiometric activation assay. Ingenol disoxate and ingenol mebutate activated all tested PKC 
A

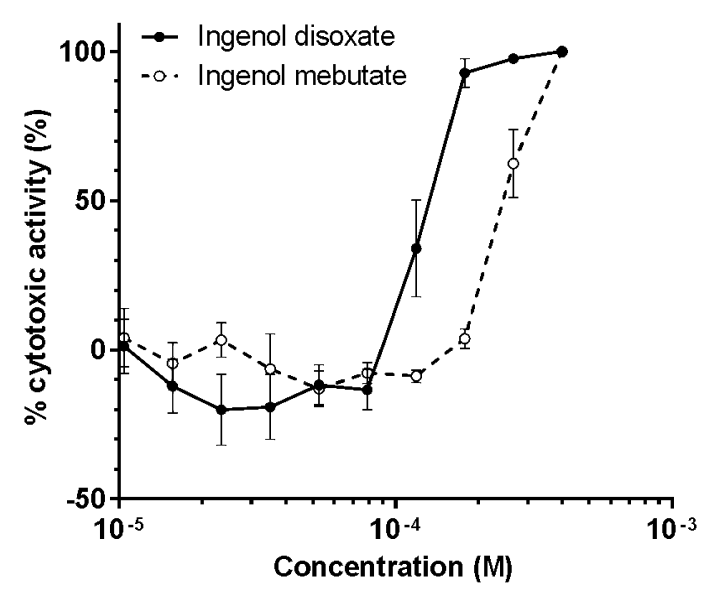

B HSC -5 cells

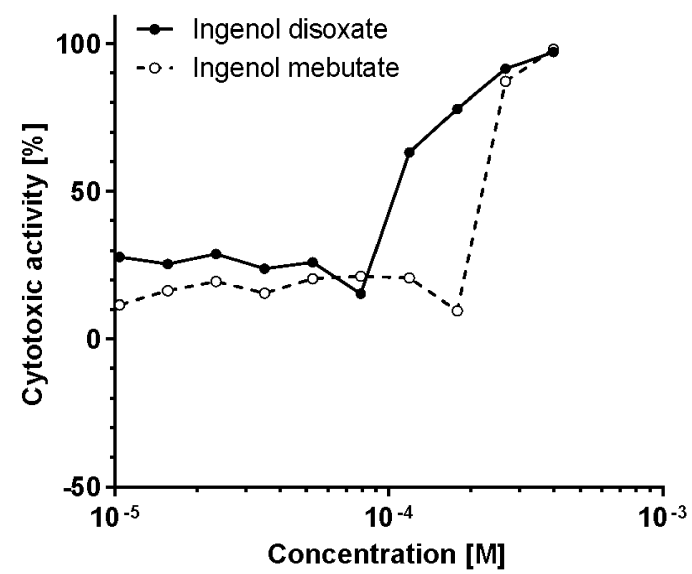

C

\begin{tabular}{l|c|c|c} 
& Cell line & $\mathrm{EC}_{50}(\mu \mathrm{M})[\mathrm{Cl95 \%}]$ & $\mathrm{N}$ \\
\hline Ingenol disoxate & HeLa & $\begin{array}{c}126[102-155] ; \\
p<0.0001\end{array}$ & 5 \\
\hline Ingenol mebutate & HeLa & $250[222-281]$ & 5 \\
\hline Ingenol disoxate & HSC-5 & 120 & 1 \\
\hline Ingenol mebutate & HSC-5 & 250 & 1
\end{tabular}

Fig. 4 Acute cytotoxicity in epithelial cancer cell lines by ingenol derivatives. a Necrotic effect in HeLa cells and b necrotic effect in HSC-5 cells following $30 \mathrm{~min}$ exposure to ingenol disoxate (closed circles) or ingenol mebutate (open circles). Plots are composites of five individual

isoforms ( $\beta \mathrm{II}, \delta, \eta, \varepsilon)$ in the low nanomolar range with similar potency and relative efficacy (Table 3). Ingenol disoxate also activated PKC $\alpha$ $\left(\mathrm{EC}_{50} 0.5 \mathrm{nM}\right), \mathrm{PKC} \gamma\left(\mathrm{EC}_{50} 0.9 \mathrm{nM}\right)$ and PKC $\left(\mathrm{EC}_{50} 11 \mathrm{nM}\right)$ with high affinity.

\section{Potent Antiproliferative Effects by Ingenol Disoxate is Paralleled by Induction of Keratinocyte Differentiation Markers}

Previous investigations have shown antiproliferative effects of PKC activation and experiments (HeLa) or a single experiment (HSC-5) and shown as mean \pm standard error of the mean. c Half-maximal cytotoxic concentrations [EC50 with 95\% confidence interval (CI 95\%)] against HeLa and HSC-5 cells were derived from sigmoidal curve fittings

ingenol mebutate treatment in both normal and malignant keratinocytes $[25,26]$. We set out to investigate if similar inhibitory effects on cell growth were induced by ingenol disoxate treatment. Following 3 days exposure we observed marked growth inhibition following either ingenol disoxate or ingenol mebutate exposure (Fig. 5).

Most notably, ingenol disoxate inhibited cell proliferation with an eightfold higher potency relative to ingenol mebutate with a half-maximal effect at $1.1 \mathrm{nM}$. Cell number 
Table 3 Ingenol disoxate and ingenol mebutate are strong activators of novel and classical PKC isoforms

\begin{tabular}{lllll}
\hline & PKC $\boldsymbol{\beta} \mathbf{I I}$ & $\mathbf{P K C}$ & $\mathbf{P K C} \boldsymbol{\eta}$ & PKC $\boldsymbol{E}$ \\
\hline Compound & $\mathrm{EC}_{50}(\mathrm{nM})(N)^{\mathrm{a}}$ & $\mathrm{EC}_{50}(\mathrm{nM})(N)^{\mathrm{a}}$ & $\mathrm{EC}_{50}(\mathrm{nM})(N)^{\mathrm{a}}$ & $\mathrm{EC}_{50}(\mathrm{nM})(N)^{\mathrm{a}}$ \\
Ingenol disoxate & $0.12 ; 0.31(2)$ & $4.3[2.5-7.2](3)$ & $3.4(1)$ & $6.5(1)$ \\
Ingenol mebutate & $0.36 ; 0.39(2)$ & $5.5[4.5-6.8](3)$ & $4.8(1)$ & $11.2 ; 4.8(2)$ \\
\hline
\end{tabular}

$C I$ confidence interval, $E C_{50}$ concentration producing $50 \%$ of the observed maximum response, $P K C$ protein kinase $\mathrm{C}$ Ingenol disoxate (3) and ingenol mebutate (1) were profiled against one classical $(\beta \mathrm{II})$ and three novel PKC isoforms $(\delta, \eta$, $\varepsilon)$ in the absence of diacylglycerol but in the presence of phosphatidylserine. Activation potencies $\left(\mathrm{EC}_{50}\right)$ were estimated from sigmoidal curve fittings

${ }^{a}$ For $N<3$ individual $\mathrm{EC}_{50}$ estimates are given. For $N=3$, geometric mean $\mathrm{EC}_{50}$ values [and $95 \%$ confidence intervals] were calculated

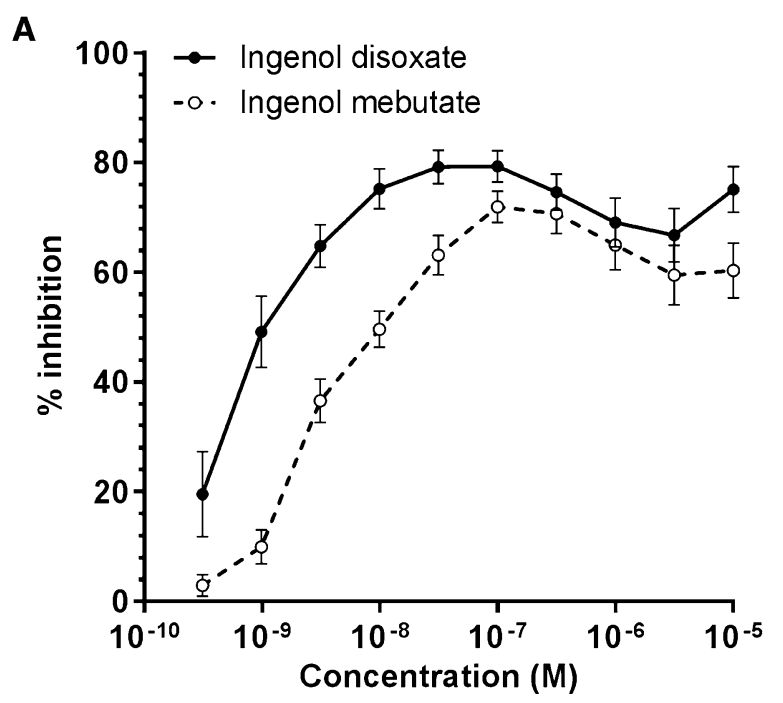

B

\begin{tabular}{l|c|c} 
& $\mathrm{EC}_{50}(\mathrm{nM})[\mathrm{Cl} 95 \%]$ & $\mathrm{N}$ \\
\hline Ingenol disoxate & $1.1[0.4-2.6], p<0.01$ & 4 \\
\hline Ingenol mebutate & $8.3[3.9-17.7]$ & 4 \\
\hline
\end{tabular}

Fig. $5 \mathrm{HeKa}$ cell growth arrest after prolonged treatment with non-acutely cytotoxic concentrations of ingenol derivatives. a Proliferation of primary human epidermal keratinocytes was assessed by measuring DNA content after exposure to increasing concentrations of ingenol disoxate (closed circles) or ingenol mebutate (open circles) for $72 \mathrm{~h}$. Plots are composites of four individual experiments (mean \pm standard error of the mean). b Half-maximal growth inhibitory concentrations [EC50 with $95 \%$ confidence interval (CI 95\%)] derived from the four independent experiments remained at levels corresponding to $20 \%$ of vehicle-treated cell cultures at concentrations above $100 \mathrm{nM}$. This is consistent with total growth inhibition of ingenol disoxate treated cells compared to vehicle-treated cells that undergo two to three cell doublings over the 72-h incubation period. Total growth inhibition without obvious signs of toxicity was also observed at concentrations from $100 \mathrm{nM}$ to $10 \mu \mathrm{M}$ for ingenol mebutate. No signs of cytotoxicity or apoptosis were observed at these concentrations. This is consistent with published data reporting that nanomolar concentrations of ingenol mebutate can efficiently initiate apoptosis in a subset of melanoma and acute myeloid leukemia cell lines, whereas another subset of cancer cells and primary cells are resistant $[27,28]$.

To further explore the mechanism underlying the antiproliferative effect we investigated if treatment could impact keratinocyte differentiation. In the epidermis of healthy skin, keratinocytes proliferate in the basal layer but commit to terminal differentiation in response to a vertical calcium gradient as they move outwards through the supra-basal layers before forming the stratum corneum barrier. This strictly 


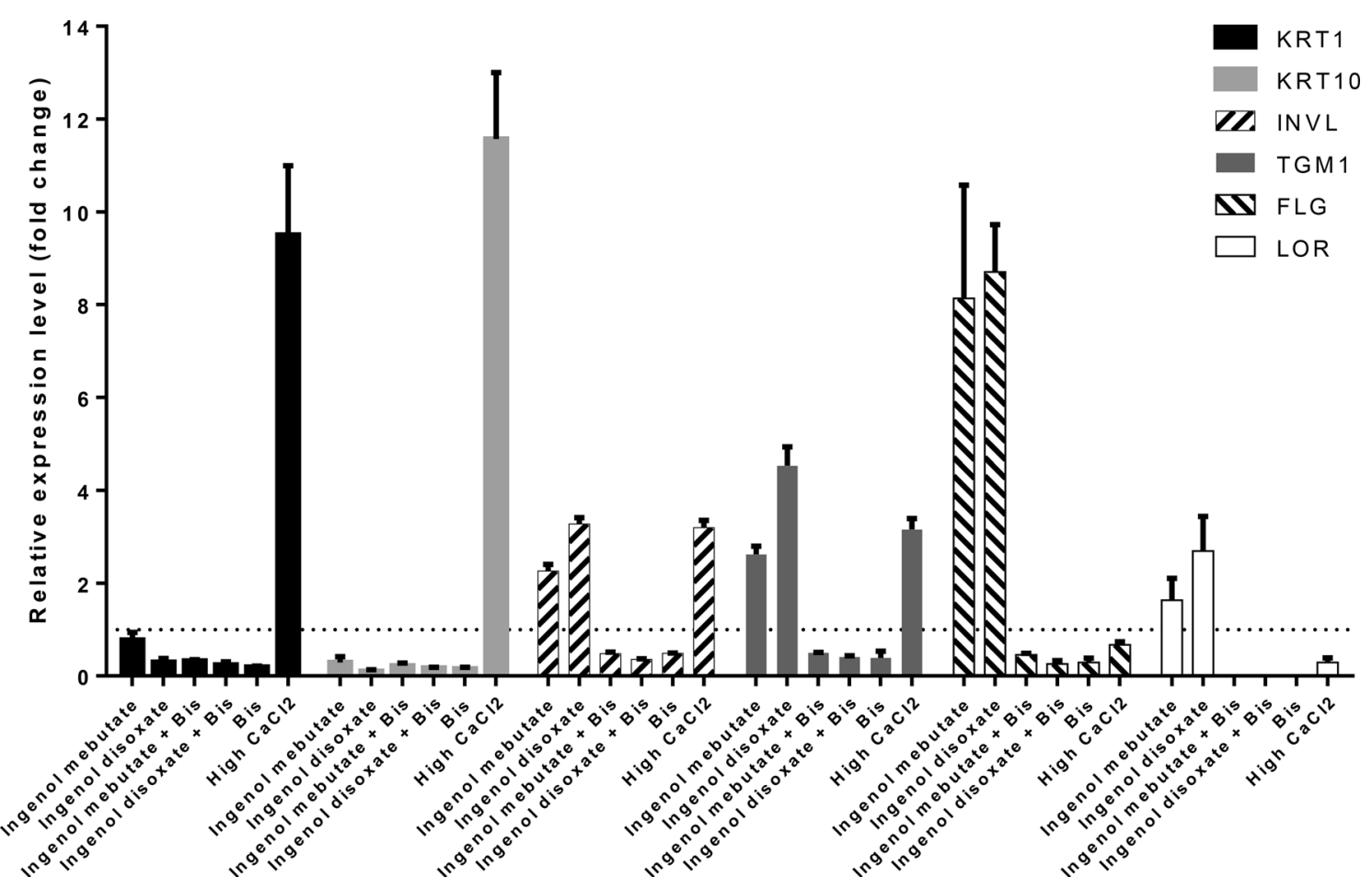

Fig. 6 PKC-dependent induction of keratinocyte differentiation markers. Primary human epidermal keratinocytes were incubated with $100 \mathrm{nM}$ ingenol disoxate or $100 \mathrm{nM}$ ingenol mebutate in low calcium medium $(0.06 \mathrm{mM}$ $\left.\mathrm{CaCl}_{2}\right)$ or exposed to high calcium medium $(1.8 \mathrm{mM}$ $\mathrm{CaCl}_{2}$ ) for $72 \mathrm{~h}$. When indicated cells were pre-incubated with $500 \mathrm{nM}$ bisindolylmaleimide I (BIS) for $30 \mathrm{~min}$ prior

regulated balance between proliferation and differentiation is profoundly disturbed in non-melanoma skin cancer. At a concentration (100 nM) inducing complete growth arrest both ingenol disoxate and ingenol mebutate stimulated transcription of intermediate (INVL) and late (TGM1, FLG, LOR) keratinocyte differentiation markers (Fig. 6).

These effects were abolished by pretreatment with bisindolylmaleimide-1; an inhibitor of novel and classical PKC isoforms. Induction of gene transcription was either on par with (INVL, TGM1) or significantly increased (FLG, LOR) relative to a calcium switch response where cells were grown in high calcium medium $\left(1.8 \mathrm{mM} \mathrm{CaCl}_{2}\right)$ for $72 \mathrm{~h}$. Transcript to exposure to $100 \mathrm{nM}$ ingenol derivatives. Markers of keratinocyte differentiation were analyzed by qPCR. Bars depict relative expression compared to vehicle-treated keratinocytes from one representative experiment (mean \pm standard error of mean). The experiment was performed in two donors with similar results

repression of early differentiation markers KRT1 and KRT10 has previously been coupled to induction of late markers, which was supported by our findings [29].

\section{Ingenol Disoxate Stimulates Keratinocyte Pro-inflammatory Cytokine Release and Neutrophil Activation}

The recruitment of neutrophil granulocytes into ingenol mebutate treatment fields has been shown to be critical for the eradication of engrafted tumors in a mouse tumor model [30]. Ingenol mebutate is believed to facilitate neutrophil granulocyte tissue infiltration via PKC-dependent mechanisms including 
upregulation of adhesion molecules on endothelial cells as well as cytokine release, in particular IL-8, from keratinocytes and other cells residing in the skin $[14,30]$. We wanted to test if ingenol disoxate was associated with a similar pro-inflammatory response at nontoxic concentrations. Therefore, we investigated the capacity to stimulate IL-8 release from keratinocytes and found that ingenol disoxate stimulated release of this cytokine with a potency $\left(\mathrm{EC}_{50}=3.3 \mathrm{nM}\right)$ and maximum efficacy comparable to ingenol mebutate (Fig. 7).

A bell-shaped dose-response curve was noted for both compounds peaking between 50 and $300 \mathrm{nM}$. A similar PKC sensitive biphasic response to ingenol mebutate treatment has previously been related to activation of different PKC isoforms [23]. The relative contribution of various PKC isoforms to the pro-inflammatory cytokine response in this study has not been further explored.

Upon tissue extravasation, neutrophil granulocytes can become activated followed by a marked and rapid increase in oxidative metabolism with generation of large amounts of reactive oxygen species (ROS) in a process referred to as the respiratory burst. This response is partly responsible for the cytotoxic actions exerted by this cell type. To monitor the generation of ROS from freshly isolated neutrophil granulocytes, we used the redox-sensitive probe hydroethidine. As shown in Fig. 8, ingenol disoxate rapidly stimulated the respiratory burst with an $\mathrm{EC}_{50}$ of $9.6 \mathrm{nM}$.

These data mirror ingenol mebutate potency and efficacy. The 5-position rearrangement product $\mathbf{8}$ was approximately tenfold and 56 -fold less potent in the IL-8 release and neutrophil activation assays, respectively, whereas the 20-ester 9 was at least 150-fold less potent in either assay (Fig. 7b).

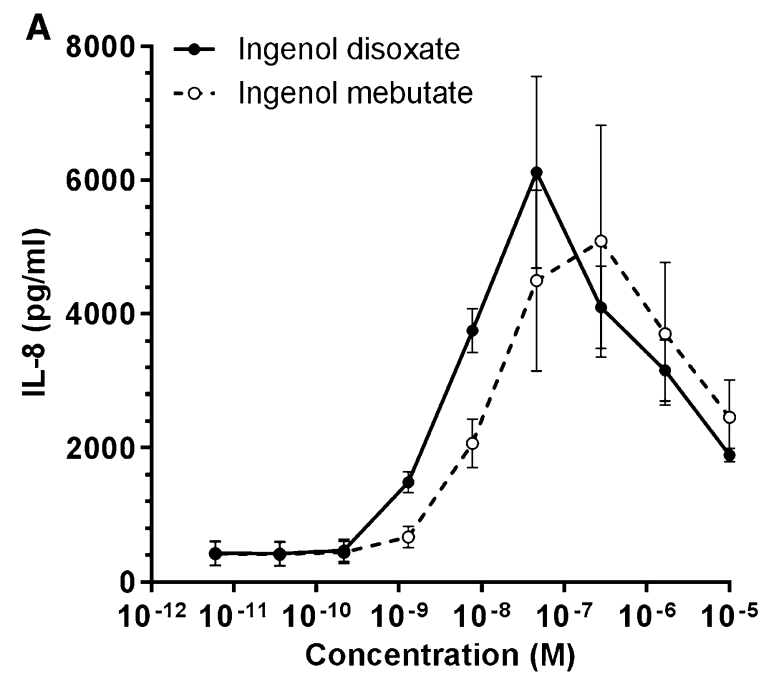

\begin{tabular}{l|c|c}
$\mathbf{B}$ & $\mathrm{EC}_{50}(\mathrm{nM})[\mathrm{Cl} 95 \%]$ & $\mathrm{N}$ \\
\hline Ingenol disoxate & $3.3[1.0-10.9] ; p<0.05$ & 4 \\
\hline Ingenol mebutate & $9.9[5.2-18.9]$ & 4 \\
\hline 5-isomer (8) & $32.4 ; 25.0$ & 2 \\
\hline 20-isomer (9) & $607 ; 486$ & 2 \\
\hline
\end{tabular}

Fig. 7 Stimulation of IL-8 secretion from keratinocytes. a Secreted IL-8 levels were quantified in the supernatant from primary human epidermal keratinocytes incubated with increasing concentrations of ingenol disoxate (closed circles) or ingenol mebutate (open circles) for $6 \mathrm{~h}$. Plots are composites of four individual experiments (mean \pm standard error of the mean). b Half-maximal stimulatory concentrations [EC50 with $95 \%$ confidence interval (CI 95\%)] of IL-8 release for ingenol disoxate, ingenol mebutate and the 5- and 20-isomers of ingenol disoxate. For $N<3$ individual EC50 estimates are given

\section{Ingenol Disoxate Exposure in Human Skin Biopsies Following Ex Vivo Topical Application is Highly Different in Epidermis and Dermis}

Next, we wanted to relate concentrations sufficient for biological activity to achievable exposure levels in human skin. Ingenol mebutate or ingenol disoxate in 


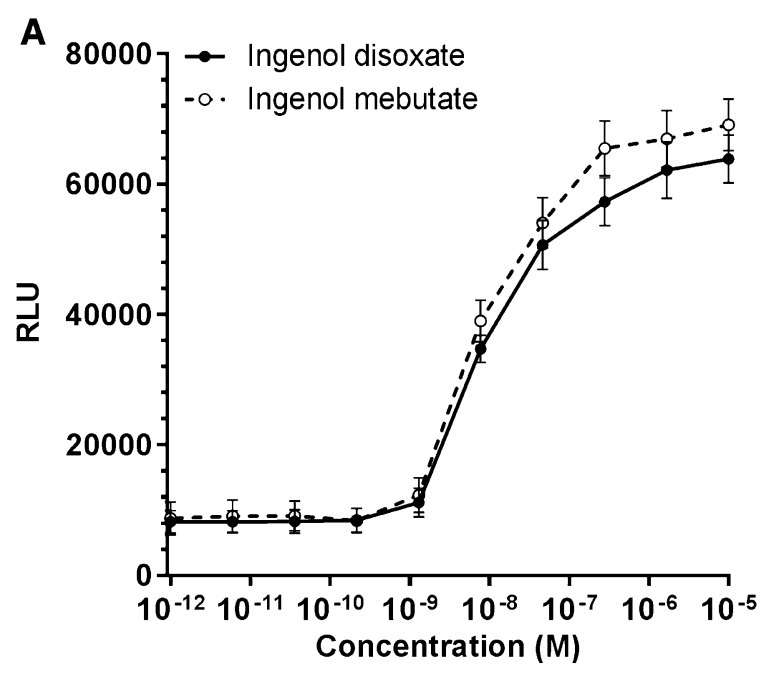

\begin{tabular}{l|c|c} 
B & EC50 (nM) [CI 95\%] & $\mathrm{N}$ \\
\hline Ingenol disoxate & $9.6[5.3-17.5] ; \mathrm{ns}$ & 4 \\
\hline Ingenol mebutate & $8.1[4.2-15.6]$ & 4 \\
\hline 5-isomer (8) & $535[152-1884]$ & 3 \\
\hline 20-isomer (9) & $>9990$ & 3 \\
\hline
\end{tabular}

Fig. 8 Stimulation of the neutrophil granulocyte respiratory burst. a The neutrophil granulocyte respiratory burst was quantified and expressed in relative light units (RLU) using the redox-sensitive probe hydroethidine in cells incubated with increasing concentrations of ingenol disoxate (closed circles) or ingenol mebutate (open circles) for $40 \mathrm{~min}$. Plots are composites of four individual experiments (mean \pm standard error of the mean). b Half-maximal stimulatory concentrations [EC50 with $95 \%$ confidence interval (CI 95\%)] of neutrophil granulocyte respiratory burst for ingenol disoxate, ingenol mebutate and the 5- and 20 -isomers of ingenol disoxate

hydroalcoholic gel (vehicle of marketed ingenol mebutate) were topically applied to freshly excised full thickness human skin biopsies. To reach a dermal concentration above the lower LOQ, a dose strength of $0.1 \%$ compound was chosen. Following 21-h incubation in a Franz diffusion cell set-up, and removal of the stratum corneum using extensive tape-stripping, the epidermal concentration levels averaged $100 \mu \mathrm{M}$ for either compound (Fig. 9).

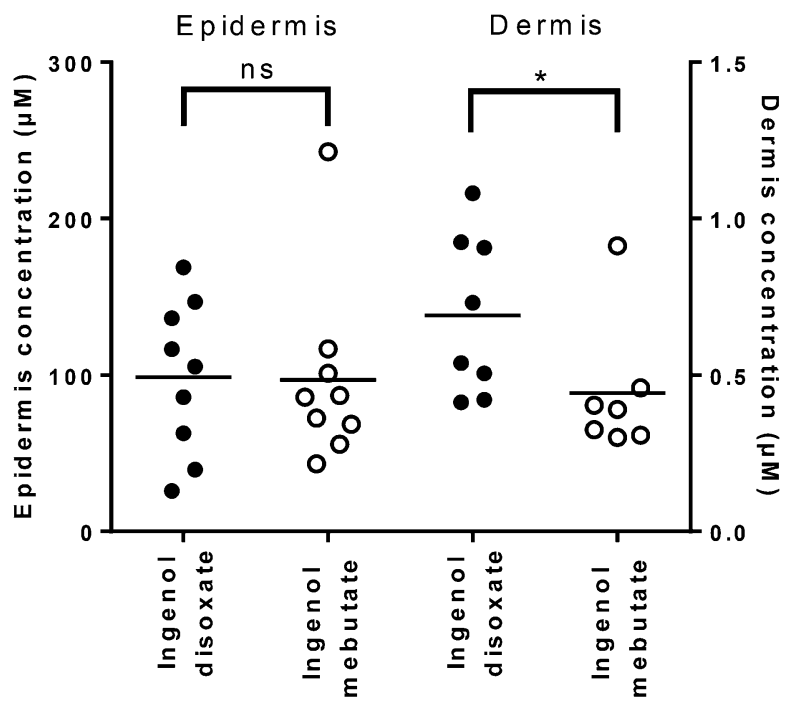

Fig. 9 Distribution of ingenol derivatives in epidermis and dermis of full thickness human skin. Ingenol disoxate or ingenol mebutate in hydroalcoholic gel formulations $(0.1 \%$ w/v) were topically applied to newly excised human skin placed in Franz cells. After $21 \mathrm{~h}$ incubation, excess formulation on the skin surface was removed and the skin was tape-stripped to remove the stratum corneum. Following heat separation, exposure levels were quantified in the epidermal and dermal skin compartments. ${ }^{*} P=0.02$ (Mann-Whitney test)

Dermal exposure levels of ingenol disoxate reached $690 \pm 257 \mathrm{nM}$ while dermal ingenol mebutate exposure levels were significantly lower averaging $364 \pm 64 \mathrm{nM}$. Thus, epidermal concentrations were more than 100-fold higher in the epidermis than in the dermis. Three of eighteen dermis samples were not quantified either because exposure levels were below lower LOQ (one ingenol mebutate sample) or because sample vials were destroyed during homogenization (one sample from either ingenol derivative treatment).

\section{Antitumor Efficacy of Ingenol Disoxate in the B16 Melanoma Mouse Model is Superior to Ingenol Mebutate}

Ingenol mebutate has been shown to be an effective treatment in mouse models with 
engrafted tumors, such as LK2 SCC cells and B16 melanoma cells, where profound necrosis extending into the subcutis leads to tumor clearance $[20,30]$. We have therefore used the B16 melanoma model to compare the in vivo tumor ablating potential of ingenol disoxate and ingenol mebutate using a dose $(0.1 \%)$ that was previously shown to be efficacious in this model [20]. Our data show that once daily topical application of an equal dose $(0.1 \%)$ of ingenol disoxate or ingenol mebutate in hydroalcoholic gel for two consecutive days significantly cured or delayed tumor growth in the B16 melanoma mouse model (Fig. 10).

In comparison, vehicle-treated tumors grew rapidly and exceeded $250 \mathrm{~mm}^{3}$ in all animals within 10 days. Most notably, the antitumor efficacy of $0.1 \%$ ingenol disoxate was significantly superior compared to $0.1 \%$ ingenol mebutate $(P<0.0036)$ with $90 \%$ of animals remaining tumor free at 3 months which is to be compared with a median survival time of 16 days and $45 \%$ overall tumor free survival in the ingenol mebutate treatment group.

When evaluating the capacity to induce acute toxicity in vitro, we found that ingenol disoxate decreased viability in mouse B16 melanoma cells with a twofold higher potency compared to ingenol mebutate (Fig. 52 in the supplementary material).

\section{LSR of Ingenol Disoxate and Ingenol Mebutate in Hairless Guinea Pigs is Similar}

The hairless guinea pig is a sensitive model of LSR. The thickness of epidermis and stratum corneum of guinea pigs skin resembles better human skin than mouse skin. Therefore, we used these animals to analyze LSR following a single topical application of ingenol disoxate and ingenol mebutate in hydroalcoholic gel. A

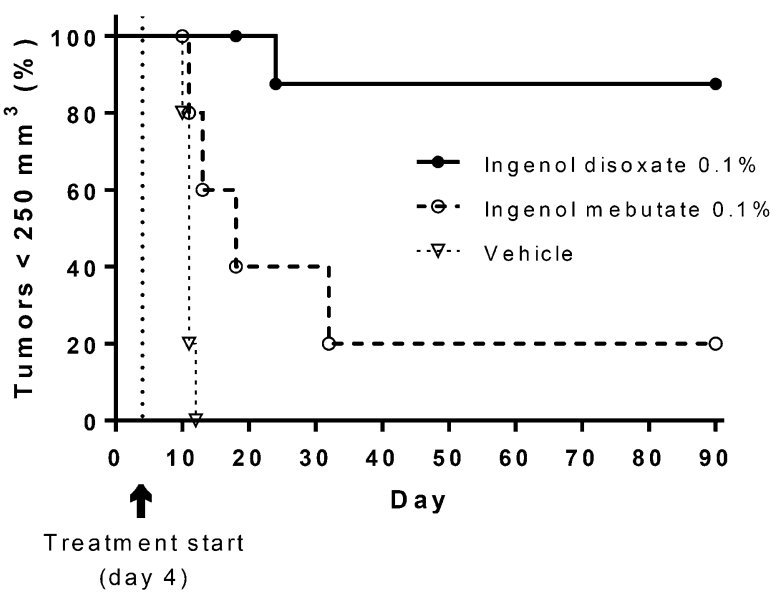

Fig. 10 Comparison of antitumor effects in the B16 melanoma mouse model. B16 murine melanoma cells were injected intradermally at day 0 in syngeneic $\mathrm{C} 57 \mathrm{BL} / 6$ mice, and the compounds were formulated at $0.1 \%$ in a hydroalcoholic gel and applied topically to the skin overlaying the injection site at day 3 and day 4 . Kaplan-Meyer survival curves are shown with 'survival' time defined as the time until the tumor exceeds $250 \mathrm{~mm}^{3}$ or ulcerates. The experiment shown is representative of four experiments with similar results

single topical application of a $0.015 \%$ and $0.05 \%$ dose strength (the clinical doses) of each compound led to a robust LSR response, resembling the response seen after treatment of human skin [7], characterized by the development of edema, erythema and ulceration that peaked after $24 \mathrm{~h}$ in all treatment groups. Skin treated with $0.05 \%$ compound had slightly higher LSR than after $0.015 \%$. There were no statistically significant differences in composite LSR between the ingenol disoxate and ingenol mebutate treatment groups (Fig. S3A and S3B in the supplementary material). Histological examination of the skin showed a comparable effect of both treatments with ballooning epidermal degeneration and varying mild degrees of infiltration of the dermis with inflammatory cells. No induction of LSR was observed with the hydroalcoholic gel alone (Fig. S3C in the supplementary material). 


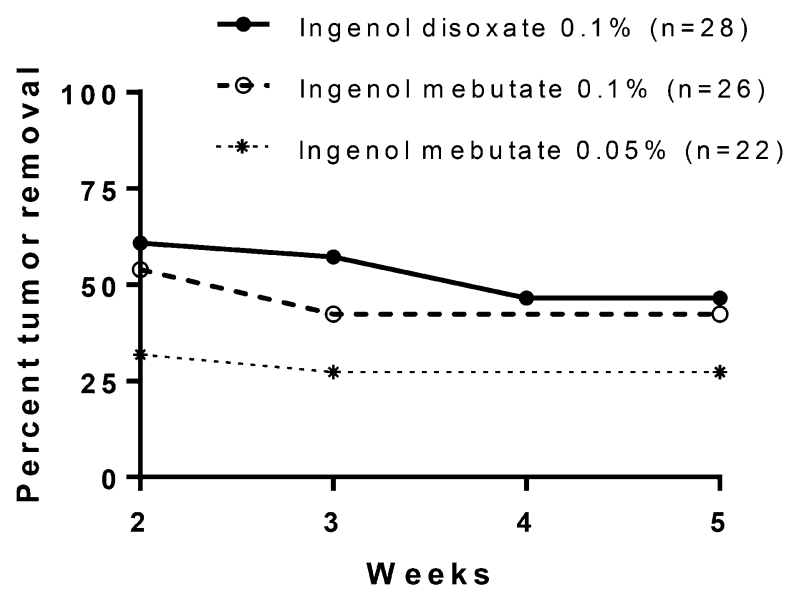

Fig. 11 Comparison of antitumor effects in a UV-induced skin cancer model. Hairless SKH1 mice were irradiated $3 \times$ weekly for 10 weeks with a minimally erythemal dose of UV, leading to appearance of skin tumors starting at week 11. Skin tumors were treated topically for two consecutive days with ingenol disoxate or ingenol mebutate in hydroalcoholic gel formulations. Treatment of tumors was done individually starting 1-2 weeks after their appearance. Kaplan-Meyer survival curves are shown with 'survival' time defined as the time until a visible tumor appears within the tattooed area. Due to the skin reaction induced by the compounds it was not possible to assess the tumors until 2 weeks after treatment

\section{Ingenol Disoxate has Antitumor Effects in a UV-Induced Skin Cancer Mouse Model}

A widely used model for skin carcinogenesis is UV-induced skin cancer in hairless mice, where repeated UV irradiations over several months lead to the development of skin tumors, primarily papillomas that finally may progress into SCC. Previous work has shown that field treatment with ingenol mebutate gel after completion of UV irradiation but before development of skin lesions leads to a reduction in tumor incidence [31]. We have used a slightly adapted model to compare the ability of ingenol mebutate and ingenol disoxate to treat UV-induced skin tumors. In our model, we treated individual tumors after they appeared with ingenol mebutate or ingenol disoxate in hydroalcoholic gel for two consecutive days. Ingenol mebutate $0.1 \%$ and ingenol disoxate $0.1 \%$ showed comparable effect, whereas ingenol mebutate $0.05 \%$ displayed a slightly weaker effect (Fig. 11). None of the tumors in untreated mice regressed spontaneously.

\section{DISCUSSION}

The marketed ingenol mebutate gel provides an effective and well-tolerated field treatment of AK characterized by a short treatment regimen and a favorable long-term outcome for the patient. However, the hydroxyl groups in the 4-, 5-, and 20-position, required for the biological activity of the active ingredient ingenol mebutate, also conveys a structural framework that facilitate isomerization via acyl migration to an extent that certain precautions are required in the distribution and handling of the drug product. Hence, we wanted to identify ingenol esters with improved chemical stability by reducing the migrating aptitude of the ester moieties on the 4-, 5- and 20-hydroxyl groups, while retaining or improving the favorable biological profile with the dual mode of action inherent to ingenol mebutate. With the discovery of ingenol disoxate we have identified a molecule that fulfills our drug candidate profile criteria in terms of both chemical stability and preclinical efficacy.

In our compound screening program, we utilized a simple chemical stability assessment in aqueous buffer $(\mathrm{pH} 7.4 ; 16 \mathrm{~h}$, room temperature) as a first tier assay [17, 18]. At these conditions $60 \%$ ingenol mebutate and at least 95\% ingenol disoxate were recovered. Several studies were conducted on the chemical entities ingenol mebutate and ingenol disoxate in clinically relevant 
formulations. Thus, both compounds formulated in the gel vehicle were stable when stored at $5{ }^{\circ} \mathrm{C}$ (Table 2). The storage of ingenol mebutate gel during accelerated conditions at $25^{\circ} \mathrm{C}$ and $60 \%$ relative humidity showed a gradual increase of the main rearrangement product (6) necessitating that ingenol mebutate is stored in the refrigerator at the patients home, whereas ingenol disoxate tolerated storage also at the accelerated conditions at $25^{\circ} \mathrm{C} / 60 \% \mathrm{RH}$ for 6 months. Hence, the physicochemical features of the substituted heterocyclic aromatic ester in ingenol disoxate provide a very favorable stability profile. This increases the potential for storage of the final product at ambient temperatures enabling improved ease of handling of the medication for the patient.

Irreversible ingenol mebutate mediated cytotoxicity is a critical parameter for the clinical efficacy of the marketed product in AK. The cell death pattern has been linked to release of calcium from intracellular organelles and disruption of the mitochondrial network with rapid loss of plasma membrane potential and integrity $[13,20]$. We demonstrate a similar acute cell death response by ingenol disoxate at micromolar concentrations in epithelial cancer cells but initiated with significantly higher potency relative to ingenol mebutate (Fig. 4). This effect was observed at concentrations which could be achieved in the epidermal compartment in ex vivo human full thickness skin biopsies $21 \mathrm{~h}$ after topical application of a clinically relevant dose (Fig. 9). We have previously reported a time-dependent decline in ingenol mebutate levels within the epidermal compartment in human skin equivalents indicating keratinocytes might have been exposed to even higher ingenol disoxate levels at earlier time points in this study [13]. Our data suggest that a direct cytotoxic effect on keratinocytes in human skin is feasible using dose strengths similar to the marketed ingenol mebutate gel.

As ingenol disoxate penetrated the skin, exposure levels gradually dropped from acutely toxic levels in the upper skin layers to concentrations sufficient for eliciting PKC activation and cell growth arrest in deeper skin regions. We show that ingenol disoxate altered the proliferative capacity of human keratinocytes and induced complete cell growth arrest at approximately $100 \mathrm{nM}$ (Fig. 5). These effects were paralleled by PKC sensitive induction of intermediate and late differentiation markers characteristic of a spinous-like and granular-like keratinocyte phenotype. A large body of evidence supports a central regulatory role of particularly PKC $\eta$ and PKC $\delta$ in the transition of keratinocytes from a proliferative to a differentiated phenotype. This is evidenced by the introduction of PKC $\eta$-null keratinocytes in 3D organotypic cultures resulting in increased epidermal thickness and delayed terminal differentiation that can be normalized by re-expression of wild-type PKC $\eta$ [32]. In another study, overexpression of $\mathrm{PKC} \eta$ and PKC $\delta$ blocked proliferation of primary human keratinocytes and increased expression and activation of transglutaminase 1 , which is involved in covalent crosslinking of protein components, such as INVL, FLG, LOR, necessary for forming the cornified envelope in terminally differentiated keratinocytes [33]. Likewise, siRNA knockdown of endogenous PKC $\delta$ inhibited calcium-induced INVL gene promoter activation [34]. Consistent with this, a recent study reported a PKC-dependent reduction in keratinocyte proliferation after prolonged ingenol mebutate treatment, which pertained to primary keratinocytes, SCC cell lines as well as patient derived SCC cells [25]. It 
remains to be established if brief exposure to nanomolar concentrations of ingenol disoxate is sufficient to alter the differentiation status of dysplastic cells, such as primary AK cells, and whether this results in terminal changes in their proliferative capacity.

A local immune response elicited by PCK activation is believed to act in concert with a direct cytotoxic effect of ingenol mebutate to drive the clinical efficacy of the marketed ingenol mebutate gel. This is supported by the presence of massive neutrophil infiltrates within treatment fields in murine engrafted tumor models and a considerable increase in tumor relapse rates in ingenol mebutate treated Foxn $1{ }^{\text {nu }}$ mice depleted of neutrophils or CD18 deficient mice characterized by impaired neutrophil extravasation [30]. Potent activation of novel and classical PKC isoforms has been linked to ingenol mebutate induced secretion of chemoattractant cytokines and expression of adhesion receptors on vascular endothelial cells necessary for neutrophil recruitment [14, 23]. These effects are believed to dominate as the drug penetrates the skin to finally reach nontoxic levels. Our data show that ingenol disoxate potently activated novel and classical PKC isoforms (Table 3), catalyzed ROS production in activated neutrophils (Fig. 8) and promoted IL-8 release from primary human keratinocytes (Fig. 7). Most notably, ingenol disoxate showed increased antitumor efficacy in the murine B16 melanoma mouse model compared to ingenol mebutate (Fig. 10a). Several explanations can potentially account for this: first, in vitro studies demonstrated that B16 cells were more susceptible to the cytotoxic actions of ingenol disoxate (Fig. 10b). Second, ingenol disoxate seemed to more efficiently penetrate the skin compared to ingenol mebutate as evidenced by relatively higher ingenol disoxate exposure levels in the dermal compartment of topically treated human skin biopsies (Fig. 9). The B16 cells reside in the reticular dermis and in the hypodermis, where the exposure level may be borderline cytotoxic; thus a higher exposure of ingenol disoxate may explain the increased tumor efficacy in this model. The difference in penetration was not anticipated based on the Potts and Guy model algorithm for topical drug penetration, which postulates a positive correlation with drug lipophilicity and a negative correlation with molecular size on skin permeability [35]. Thus, the small increase in the measured ingenol disoxate distribution coefficient $(\log \mathrm{D})$ was only moderate (3.9 versus 3.5 ) relative to the slightly smaller sized ingenol mebutate with an expected minimal effect on drug skin permeability. However, it should be emphasized that it is unclear how well the datasets used for deriving Potts and Guy equations represent the ingenol type of compounds as, for example, steroids have been identified as outliers in the correlation [36]. Third, chemical stability measurements at $37^{\circ} \mathrm{C}$ in an aqueous buffer (pH 7.4) demonstrated higher relative recoveries of ingenol disoxate relative to ingenol mebutate, i.e., about $98 \%$ and $73 \%$ ingenol disoxate and $63 \%$ and $44 \%$ ingenol mebutate after 2 and $24 \mathrm{~h}$, respectively (Fig. 3). It is unclear to which extent the stability determined in aqueous buffer translates to drug stability within the skin milieu. However, a higher propensity of ingenol mebutate towards progressive rearrangement to the significantly less potent 5 - and 20-isomers $(6,7)$ within the extracellular fluid may offer an alternative explanation for the superior in vivo efficacy of ingenol disoxate. Although data indicated relatively higher ingenol disoxate skin exposure levels, the magnitude and temporal pattern of the local skin response (LSR) mirrored the effect of 
ingenol mebutate in the hairless guinea pig; an extensively used model to assess LSRs [37]. Translation to the clinical setting has subsequently been confirmed by the demonstration of a similar LSR profile of ingenol mebutate and ingenol disoxate at similar dose strengths in patients with AK [38].

We extended our skin carcinogenesis studies to the hairless and immune-competent SKH1/hr mouse which spontaneously develops tumors following multiple UVR exposures. The model is characterized by the promotion of UV damaged keratinocytes into premalignant exophytic papillomas that finally progress into SCCs breaching the basement membrane and invading the dermis. In the current model, treatment intervention was initiated before papillomas developed into malignant invasive tumors. Our data demonstrate more than 50\% tumor clearance for both ingenol disoxate and ingenol mebutate at similar doses, which was largely maintained 5 weeks post treatment (Fig. 11). Since atypical cells are only located in superficial skin layers, drug exposure levels following either treatment were sufficient to eradicate a large proportion of aberrant cells. These results support the use of ingenol disoxate in skin malignancies initiated by accumulated UVR exposure.

\section{CONCLUSIONS}

Ingenol disoxate (LEO 43204) is a novel ingenol derivative with significantly improved chemical stability compared to the marketed ingenol mebutate gel, potentially enabling the patient to store the final product at ambient temperatures. Key features inherent to ingenol mebutate were preserved in ingenol disoxate providing a similar dual mechanism of action with acute induction of cell death and PKC-mediated cell growth arrest and induction of a pro-inflammatory response. With the discovery of ingenol disoxate we have identified a molecule that fulfills our drug candidate profile criteria in terms of both chemical stability and preclinical efficacy. Ingenol disoxate is currently in Phase 3 clinical development and was recently shown to be an efficacious and well-tolerated topical field treatment for $\mathrm{AK}$, further underscoring the therapeutic potential of this novel ingenol derivative in non-melanoma skin cancers [38].

\section{ACKNOWLEDGMENTS}

We acknowledge Thomas Vifian, Anders Klarskov Petersen, Svitlana Tkach, Karin Kryger, Nina Ravn Borch, Ninette Winther Hansen, Nannette Svendsen, Hanne Rosendal, Lene Torp-Milojevic, Dina Wennike, Majbritt Nielsen, Tinna Nielsen, Gitte Lund, Pernille Christensen, Marianne Petersen and Susanne Strøm for skillful technical assistance, Kåre Engkilde for valuable scientific input to the studies and for critical reading of the manuscript, André Huss Eriksson for valuable input to the Franz chamber study, Maria Høyer-Hansen for the design of the guinea pig study and many colleagues at LEO Pharma for constructive discussions. All named authors meet the International Committee of Medical Journal Editors (ICMJE) criteria for authorship for this manuscript, take responsibility for the integrity of the work as a whole, and have given final approval to the version to be published. Sponsorship and article processing charges for this study were funded by LEO Pharma.

Disclosures. Malene Bertelsen, Martin Stahlhut, Gunnar Grue-Sørensen, Xifu Liang, Gitte Bach Christensen, Kresten Skak, Karen Margrethe Engell, and Thomas Högberg are or 
have been (G G-S, G B C) employed by LEO Pharma, who holds the commercial and intellectual rights to ingenol mebutate and ingenol disoxate. This study was entirely funded by LEO Pharma.

Compliance with Ethics Guidelines. All institutional and national guidelines for the care and use of laboratory animals were followed. For the human skin studies, full thickness human skin was sourced from abdominal surgery from the Department of Plastic Surgery, Herlev Hospital, Denmark. The identities of the donors were not known to LEO Pharma; the tissues were not extracted for the purpose of this study and none of the authors were involved in the collection of the tissue samples. According to the Danish Committee Act section 143, the use of anonymous human biological material in health research projects does not require ethical approval if the human biological material has been collected in accordance with national legislation in the country of origin, which is the case in this study.

Open Access. This article is distributed under the terms of the Creative Commons Attribution-NonCommercial 4.0 International License (http://creativecommons.org/licenses/ by-nc/4.0/), which permits any noncommercial use, distribution, and reproduction in any medium, provided you give appropriate credit to the original author(s) and the source, provide a link to the Creative Commons license, and indicate if changes were made.

\section{REFERENCES}

1. Roewert-Huber J, Stockfleth E, Kerl H. Pathology and pathobiology of actinic (solar) keratosis-an update. Br J Dermatol. 2007;157(Suppl 2):18-20.
2. Schmitt JV, Miot HA. Actinic keratosis: a clinical and epidemiological revision. An Bras Dermatol. 2012;87(3):425-34.

3. Berman B, Cockerell CJ. Pathobiology of actinic keratosis: ultraviolet-dependent keratinocyte proliferation. J Am Acad Dermatol. 2013;68(1 Suppl 1):S10-9.

4. Nashan D, Meiss F, Muller M. Therapeutic strategies for actinic keratoses-a systematic review. Eur J Dermatol. 2013;23(1):14-32.

5. Samrao A, Cockerell CJ. Pharmacotherapeutic management of actinic keratosis: focus on newer topical agents. Am J Clin Dermatol. 2013;14(4):273-7.

6. Samrao A, Cockerell CJ. Pharmacotherapeutic management of actinic keratosis: focus on newer topical agents. Am J Clin Dermatol. 2013;14(4):273-7.

7. Lebwohl M, Swanson N, Anderson LL, Melgaard A, $\mathrm{Xu} \mathrm{Z}$, Berman B. Ingenol mebutate gel for actinic keratosis. N Engl J Med. 2012;366(11):1010-9.

8. Ali FR, Wlodek C, Lear JT. The role of ingenol mebutate in the treatment of actinic keratoses. Dermatol Ther (Heidelb). 2012;2(1):8.

9. Vasas A, Redei D, Csupor D, Molnar J, Hohmann J. Diterpenes from European Euphorbia species serving as prototypes for natural-product-based drug discovery. Eur J Org Chem. 2015;2012(27):5115-30.

10. Hohmann J, Evanics F, Berta L, Bartok T. Diterpenoids from Euphorbia peplus. Planta Med. 2000;66(3):291-4.

11. Liang X, Grue-Sorensen G, Petersen A, Hoegberg T. Semisynthesis of ingenol 3-angelate (PEP005): efficient stereoconservative angeloylation of alcohols. Synlett. 2012;23:2647-52.

12. Lebwohl M, Shumack S, Stein GL, Melgaard A, Larsson T, Tyring SK. Long-term follow-up study of ingenol mebutate gel for the treatment of actinic keratoses. JAMA Dermatol. 2013;149(6):666-70.

13. Stahlhut $M$, Bertelsen $M$, Hoyer-Hansen $M$, Svendsen N, Eriksson AH, Lord JM, et al. Ingenol mebutate: induced cell death patterns in normal and cancer epithelial cells. J Drugs Dermatol. 2012;11(10):1181-92.

14. Hampson P, Kavanagh D, Smith E, Wang K, Lord JM, Ed RG. The antitumor agent, ingenol-3-angelate (PEP005), promotes the recruitment of cytotoxic neutrophils by activation of vascular endothelial cells in a PKC-delta 
dependent manner. Cancer Immunol Immunother. 2008;57(8):1241-51.

15. Ersvaer E, Kittang AO, Hampson P, Sand K, Gjertsen $\mathrm{BT}$, Lord JM, et al. The protein kinase $\mathrm{C}$ agonist PEP005 (ingenol 3-angelate) in the treatment of human cancer: a balance between efficacy and toxicity. Toxins (Basel). 2010;2(1):174-94.

16. Rosen RH, Gupta AK, Tyring SK. Dual mechanism of action of ingenol mebutate gel for topical treatment of actinic keratoses: rapid lesion necrosis followed by lesion-specific immune response. J Am Acad Dermatol. 2012;66(3):486-93.

17. Liang X, Grue-Sorensen G, Mansson K, Vedso P, Soor A, Stahlhut M, et al. Syntheses, biological evaluation and SAR of ingenol mebutate analogues for treatment of actinic keratosis and non-melanoma skin cancer. Bioorg Med Chem Lett. 2013;23(20):5624-9.

18. Grue-Sorensen G, Liang X, Mansson K, Vedso P, Dahl SM, Soor A, et al. Synthesis, biological evaluation and SAR of 3-benzoates of ingenol for treatment of actinic keratosis and non-melanoma skin cancer. Bioorg Med Chem Lett. 2014;24(1):54-60.

19. Jin Y, Yeh CH, Kuttruff CA, Jorgensen L, Dunstl G, Felding J, et al. $\mathrm{CH}$ oxidation of ingenanes enables potent and selective protein kinase $\mathrm{C}$ isoform activation. Angew Chem Int Ed Engl. 2015;54(47):14044-8.

20. Ogbourne SM, Suhrbier A, Jones B, Cozzi SJ, Boyle GM, Morris M, et al. Antitumor activity of 3-ingenyl angelate: plasma membrane and mitochondrial disruption and necrotic cell death. Cancer Res. 2004;64(8):2833-9.

21. Newton AC. Protein kinase C: structure, function, and regulation. J Biol Chem. $1995 ; 270(48): 28495-8$.

22. Nishizuka Y. Protein kinase $\mathrm{C}$ and lipid signaling for sustained cellular responses. FASEB J. 1995;9(7):484-96.

23. Kedei N, Lundberg DJ, Toth A, Welburn P, Garfield $\mathrm{SH}$, Blumberg PM. Characterization of the interaction of ingenol 3-angelate with protein kinase C. Cancer Res. 2004;64(9):3243-55.

24. Fisher GJ, Tavakkol A, Leach K, Burns D, Basta P, Loomis C, et al. Differential expression of protein kinase $\mathrm{C}$ isoenzymes in normal and psoriatic adult human skin: reduced expression of protein kinase C-beta II in psoriasis. J Invest Dermatol. 1993;101(4):553-9.
25. Freiberger SN, Cheng PF, Iotzova-Weiss G, Neu J, Liu Q, Dziunycz PJ, et al. Ingenol mebutate signals via PKC/MEK/ERK in keratinocytes and induces interleukin decoy receptors IL1R2 and IL13RA2. Mol Cancer Ther. 2015;14:2132-42.

26. Jerome-Morais A, Rahn HR, Tibudan SS, Denning MF. Role for protein kinase C-alpha in keratinocyte growth arrest. J Invest Dermatol. 2009;129(10):2365-75.

27. Hampson $\mathrm{P}$, Chahal $\mathrm{H}$, Khanim $\mathrm{F}$, Hayden $\mathrm{R}$, Mulder A, Assi LK, et al. PEP005, a selective small-molecule activator of protein kinase C, has potent antileukemic activity mediated via the delta isoform of PKC. Blood. 2005;106(4):1362-8.

28. Gillespie SK, Zhang XD, Hersey P. Ingenol 3-angelate induces dual modes of cell death and differentially regulates tumor necrosis factor-related apoptosis-inducing ligand-induced apoptosis in melanoma cells. Mol Cancer Ther. 2004;3(12):1651-8.

29. Dlugosz AA, Yuspa SH. Coordinate changes in gene expression which mark the spinous to granular cell transition in epidermis are regulated by protein kinase C. J Cell Biol. 1993;120(1):217-25.

30. Challacombe JM, Suhrbier A, Parsons PG, Jones B, Hampson P, Kavanagh D, et al. Neutrophils are a key component of the antitumor efficacy of topical chemotherapy with ingenol-3-angelate. J Immunol. 2006;177(11):8123-32.

31. Cozzi SJ, Ogbourne SM, James C, Rebel HG, de Gruijl FR, Ferguson B, et al. Ingenol mebutate field-directed treatment of UVB-damaged skin reduces lesion formation and removes mutant p53 patches. J Invest Dermatol. 2012;132(4):1263-71.

32. Hara T, Miyazaki M, Hakuno F, Takahashi S, Chida K. PKCeta promotes a proliferation to differentiation switch in keratinocytes via upregulation of p27Kip1 mRNA through suppression of JNK/C-Jun signaling under stress conditions. Cell Death Dis. 2011;2:e157.

33. Ohba M, Ishino K, Kashiwagi M, Kawabe S, Chida K, Huh $\mathrm{NH}$, et al. Induction of differentiation in normal human keratinocytes by adenovirus-mediated introduction of the eta and delta isoforms of protein kinase C. Mol Cell Biol. 1998;18(9):5199-207.

34. Adhikary G, Chew YC, Reece EA, Eckert RL. PKC-delta and -eta, MEKK-1, MEK-6, MEK-3, and p38-delta are essential mediators of the response of normal human epidermal keratinocytes to differentiating agents. J Invest Dermatol. 2010;130(8):2017-30. 
35. Potts RO, Guy RH. Predicting skin permeability. Pharm Res. 1992;9(5):663-9.

36. Cronin MTD, Hewitt M. Comprehensive medicinal chemistry II, 2nd edn. Elsevier, Amsterdam; 2007. pp 725-44.

37. Kimber I, Basketter DA, Berthold K, Butler $\mathrm{M}$, Garrigue JL, Lea L, et al. Skin sensitization testing in potency and risk assessment. Toxicol Sci. 2001;59(2):198-208.

38. Sinnya S, Tan JM, Prow TW, Primiero C, McEniery E, Selmer J, et al. A randomized, phase IIa exploratory trial to assess the safety and preliminary efficacy of LEO 43204 in patients with actinic keratosis. $\mathrm{Br} \quad \mathrm{J}$ Dermatol. 2016;174(2):305-11. 